Article

\title{
Towards Adaptive Commons: A Case Study of Agro-Pastoral Dams in Northern Ghana
}

\author{
Ruben Weesie
}

Department of Human Geography and Planning, Utrecht University, 3584 CB Utrecht, The Netherlands; r.v.weesie@uu.nl or rubenweesie@gmail.com; Tel.: +31-618-154-497

Received: 30 September 2018; Accepted: 2 January 2019; Published: 10 January 2019

\begin{abstract}
Agro-pastoral dams (APDs) are an increasingly popular method of adaptation interventions improving communal water supply in rural West Africa. However, APDs are often constructed in areas where culturally heterogeneous pastoralists and farmers compete for similar land and water resources. Lifting open access water abundance is likely to change if not intensify ongoing tensions between farmers and settling Fulani herders. The extent of collective action and inclusivity of 6 APDs in Northern Ghana are analysed, combining theory from common-pool resource management and equity and justice in climate change adaptation into a proposed Inclusive Collective Action (ICA) model. Practically, the article demonstrates that neither fully excluding Fulani pastoralists nor making dams openly accessible results in inclusive APD usage and management where collective action is successful, and more dynamic forms of regional inclusion and exclusion are needed. Theoretically, the article identifies some of the limitations of applying the enabling conditions for collective action of common-pool resource theory as it tends to overlook negative aspects of excluding certain user groups in culturally heterogeneous contexts from managing and using a commons.
\end{abstract}

Keywords: agro-pastoral dams; collective action; conflict; inclusivity; Ghana; common-pool resource management; adaptation interventions; sustainability

\section{Introduction}

In rural West Africa, farmers and pastoralists are often strongly exposed to changes in the climate due to their direct reliance on natural resources such as rainwater and pasture. Recognising this issue, numerous development projects have attempted to improve security of perennial water access by constructing agro-pastoral dams (APDs) in West African villages. APDs are basically dugouts open for public use, in order to provide water for both livestock and agricultural activities for one or several villages [1]. The APDs are constructed in order to support the rural villages in tackling poverty and adapting to the changing climate by stimulating the development of both livestock and crop production. APDs have been constructed since the 1990s, and fit within the popular trend in the community-based adaptation (CBA) approach for governmental and non-governmental project interventions. CBA interventions are projects deliberately designed and implemented to enhance/improve target communities resilience to impacts of climate change [2]. CBA thereby assumes that the village or community is the proper scale to apply interventions to improve resilience to climate change in a participatory, bottom-up manner. As a result of the recent COP21 in Paris, more and more funding to help communities adapt to climate change is to be released as from 2020. It will trigger a plethora of CBA interventions aiming to create water abundance mainly for farming and herding purposes in the water-scarce areas throughout the developing world including West Africa. Therefore, CBA and other interventions that construct and/or rehabilitate APDs in West Africa are likely to be even more widespread in the future. However, the establishment of APDs in West African communities is not unproblematic. The APDs are prone to degrade if not maintained well, and the newly available 
water attracts both farmers and pastoralists from the community and its surroundings that compete over using the water and surrounding land. As APDs are generally publicly accessible and it is difficult to exclude certain users, these can be considered common-pool resources (CPRs) or 'commons' (after [3]). Competition over the commons is widespread in West Africa, often leading to conflict between farmers and pastoralists that compete over using publicly accessible land and water resources. For example, such conflict erupts when livestock destroys crops and farmers sometimes retaliate by killing cattle, leading to a breakdown of farmer-pastoralist relations [4-8]. Such conflicts over the commons usually takes place along socio-cultural cleavages, where farmers belong to sedentary ethnic groups within national boundaries while pastoralists often belong to the widespread Fulani ethnic group. The ongoing competition is likely to be affected by CBA interventions on APDs as these lift water abundance in previously water-scarce areas. In these areas, conflict is not necessarily related to resource scarcity but rather to availability [9]. Competing claims and commons-related conflict is likely to continue, as groups of Fulani pastoralists continue to migrate southward and settle into the Guinea Savannah Belt as a result of degradation of pasture in the Sahel region [9].

This article proposes and uses a model called the Inclusive Collective Action (ICA) model to gain insights on how CBA interventions that seek to rehabilitate or construct APDs can contribute to successful dam usage and management. Such knowledge is direly needed to prevent further degradation of existing APDs, and to prevent possible conflict between farmers and Fulani pastoralists related to the existing and new APDs to be constructed. In order to obtain such knowledge, this research analysed the likelihood for collective action and inclusiveness of several communities with APDs in Northern Ghana. The six studied communities are future beneficiaries of internationally funded CBA interventions that seek to (re)construct the APDs the coming years. By diagnosing the current APD systems in the studied region, suggestions can be made as to how the planned CBA interventions on APDs can have more successful and inclusive results than what has been achieved so far. The results therefore feed theoretically into commons theory, and practically into the implementation process of the planned interventions.

\section{Theory}

Commons scholars could have predicted the unsustainable and conflict-prone situation concerning APDs that emerged in West Africa, because there are two contextual characteristics they see to hinder the development of successful commons management. First, socio-cultural heterogeneity of groups using a commons is seen as an obstacle regarding successful governance of these commons [3,10-12]. Second, commons theory proposes that commons users need to be able to exclude other people from using their commons in order to manage it successfully (c.f. $[3,11])$. And if some resource users cannot exclude others from using the same resource, Hardin's famous notion of a Tragedy of the Commons is likely to occur: a resource is inevitably overused by competing users up to a point where its supply collapses [13]. Promoting socio-cultural homogeneity of APD beneficiary communities and their power to exclude others is however highly unrealistic and undesirable in the West African context if these interventions aim to be pro-poor and allocate CBA intervention benefits equitably. In Namibia, for example, marginalization resulting from a CBA intervention on a common water resource occurred, where borehole pumps and pipeline-accessing taps were installed and committees were trained to manage these water supplies during an intervention. After the intervention was completed, there were cases of exploitation and individuals having to work for local elites to gain access to these water resources when they were unable to fulfil monthly payments to the local water point committees [14]. People in rural regions using commons such as water and pasture may often be culturally diverse, where different ethnic groups may use similar commons for different purposes. In West African regions specifically, there is widespread competition for land and water resources between sedentary farmers belonging to a different ethnic group than the Fulani pastoralists they compete with. Excludability of the commons is low as for example fencing of pasture and water points is too costly and excluding people from using previously open access water is often culturally 
unacceptable. It is often recognised that in such agro-pastoral contexts, the mobile, transhumant mode of livestock keeping demands a flexible tenure regime based on non-exclusive use rights to pasture and water resources [15]. As such, current commons theory provides no insights yet on how CBA interventions that provide new commons abundance can contribute to more successful usage and management that includes culturally diverse user groups.

In an attempt to provide such necessary insights, this research analysed APDs by employing a combination of the concepts of collective action and equity. Collective action, in this case the cooperation between common-pool resource users, is widely seen as a requirement for successful and sustainable commons usage and management [16], and for adapting to climate change in developing countries in general [17]. Collective action is often defined as the coordination of efforts among groups of individuals to achieve a common goal when individual self-interest would be inadequate to achieve the desired outcome [3]. CBA literature follows this line of reasoning, as CBA is based on the premise that "local communities have the skills, experience, local knowledge and networks to undertake locally appropriate activities that increase resilience and reduce vulnerability to a range of factors including climate change" [2]. Undertaking 'locally appropriate activities' indicates the importance of collective action for communities which they need to manage their commons in order to adapt to climate change.

Commons scholars state that there are several necessary preconditions to the successful implementation of collective actions associated with the design of institutions, the nature of the group, and the nature of the resource [3]. Agrawal [11] formulated a list of enabling conditions for collective action which needs to be adhered to increase the likelihood of successful collective action of commons users and managers. These factors include resource characteristics such as clearly defined boundaries, user group characteristics such as having shared norms and a small size. Furthermore it includes user-resource relationships such as a high dependence of the users on the resource, and a supportive external environment such as a government that does not undermine local authority (see left column Table A1).

With a focus on collective action, commons literature has been preoccupied with self-governance and the search for identifying factors that affect the success of communities themselves in governing their commons $[10,18]$. However, in the context of areas recipient to adaptation interventions, the management of local commons is also influenced by state actors, international donors, NGOs and other community developers. Even when not formally mentioned in regulations and government policy guidelines and documents, many community developers are involved in supporting communities in governing their commons [18]. While the necessity of collective action for governing commons has been recognized in participatory and CBA development projects, translating the findings of commons literature into intervention strategies is difficult [18]. It remains unclear to what extent external actors can support communities in governing commons successfully. Van Laerhoven \& Barnes [18] recognized this issue, and decided for each enabling condition whether these can be manipulated with external projects such as CBA interventions (see right column Table A1). According to the list of conditions for enabling successful CPR governance, they $[19,20]$ hypothesize that only some of these are possible to manipulate or 'manipulatable' by external interventions. Making the distinction between manipulatable and non-manipulatable factors—which can also influence each other [11] —is useful: external interventions can then think of what to focus on in order to promote successful commons governance. Obviously, what enabling conditions are manipulatable with interventions or not also depends on context.

While the design principles are statistically correlated with successful CPR systems [21], single design principles cannot explain success for every CPR. Instead, clusters of principles are needed, and its effects are contingent on the characteristics of the CPR [22]. The question for this study then is, what clusters of manipulatable enabling conditions CBA interventions should focus on in the case of APDs in Northern Ghana.

The second theoretical concept used in the theoretical framework is the principle of equity or 'inclusivity'. Equity in climate change adaptation refers to the equitability of allocation of 
intervention benefits [23]. As Twyman et al. [14] demonstrated with their Namibia boreholes case study mentioned earlier, empowerment of communities in the name of CBA is not a simple recipe for the generation of justice and often desired equitable outcomes at community and household level. With the exploitation and exclusion of the vulnerable from accessing water made available with a CBA intervention, it is clear that policy which sees decentralization of resource management as the key to empowering local communities ignores possible adverse effects for equity in resource access [23]. As such, community-based resource management may in fact create differentiated access to resources [24-26]. However, adaptive capacity of target communities becomes greater if access to resources is equitably distributed (cf. $[27,28]$ ) - the general goal of CBA interventions. Inclusivity in this research encompasses the degree to which different (potential) resource users (farmers and pastoralists) with varying socio-economic and socio-cultural characteristics are able to be involved in using and managing a commons.

The concepts of inclusivity and collective action are combined into a theoretical model called the Inclusive Collective Action (ICA) model. It diagnoses the different levels of collective action and inclusivity of a commons, and can be used to analyse and suggest how CBA interventions can manipulate commons cases into scenarios where collective action and inclusion of different user groups is more likely. The likelihood of collective action in commons usage is based on the number of enabling conditions that are adhered. The inclusivity of the CPR usage is based on to what extent different users with varying socio-economic, socio-cultural and spatial-temporal characteristics are able to be involved in using and managing the commons. The ICA model introduces a typology of four possible CPR usage and management types.

1. The first type is a 'maladaptive club', a resource where likelihood for collective action is low and from which potential users are excluded. As a low number of enabling conditions are adhered, collective action by resource users is unsuccessful. As exclusion takes place by people towards other people that aim to use the resource, the group using the resource can be called a 'club' (after [18]).

2. The second type is a 'maladaptive commons' scenario, which is a resource that is inclusively used as none or hardly anyone is excluded from using it, and can therefore still be defined as a commons, while collective action by users is unsuccessful in the management of the commons.

3. The third possible scenario is an 'adaptive club', a resource where people are excluded from and only a selection of users can use it, while collective action by its users is likely. Various enabling conditions are adhered, such as sufficient maintenance and overuse is prevented.

4. The last scenario are 'adaptive commons' that both include a variety of users and tend not to rigidly exclude certain groups, while collective action is likely. This scenario is perhaps most desired to achieve by adaptation interventions because it is likely to be the most sustainable and equitable.

Important to realise is that the typology of four CPR usages above are extremes, of which in reality intermediate forms may often exist. The ICA model with the four different types of CPR usage based on extent of collective action and inclusivity is shown in Figure 1 below. 


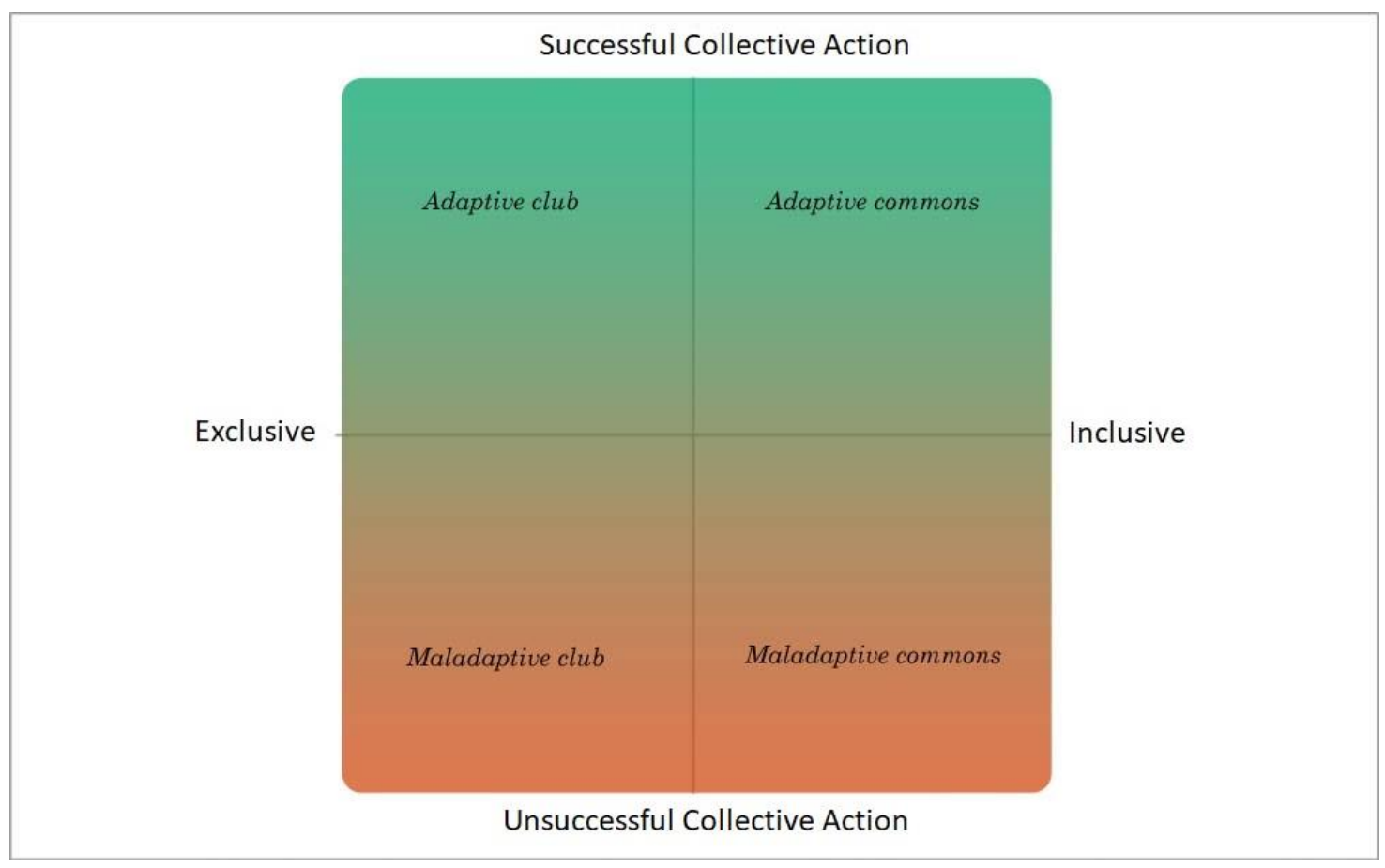

Figure 1. Inclusive Collective Action (ICA) model distinguishes four types of CPR usages that can be manipulated with outside interventions (by author).

\section{Materials and Methods}

\subsection{Operationalisation of Collective Action and Inclusivity}

Successful collective action of the APDs is rated using the enabling conditions for collective action concerning CPRs (see Table A1). Each dam is separately analysed as a CPR, and each enabling condition is reformulated to fit the regional dam's context. The operationalization of each enabling condition for collective action fitting the research context is demonstrated in Table A2. For the purpose of structuring and simplifying the analysis, the indicators defining the are answered dichotomously with a yes or no.

In this study, inclusivity is analysed socio-economically and socio-culturally. Socio-economic inclusivity basically refers to the socio-economic diversity of the dry season farmers using the dam. It is determined by whether they use chemical fertilizer, whether they make investments to maintain the water supply, where they buy their seeds, what crops are grown. Usage of chemical fertilizer is assumed to be used by non-poor farmers, meaning that the larger the number of farmers that use chemical fertilizer is, the smaller the number of poor farmers is assumed to be. The extent to which chemical fertilizer is used is then compared to the overall estimated wealth distribution of each studied community. If a large percentage of farmers use chemical fertilizer while a large percentage of the village is considered poor, socio-economic diversity of the farmers is considered low as the farmers tend to be the relatively rich. And vice versa, if only a few farmers use chemical fertilizer and the village tends to be poor, socio-economic diversity is considered higher as it better reflects the village's wealth distribution.

Socio-cultural inclusivity refers to what extent Fulani are allowed to use the dam and allowed to settle in the studied communities, and allowed to own cattle. It is determined by 5 variables: the number of Fulani families the community hosts, whether they are allowed to own cattle, whether Fulani from outside (settled in neighbouring communities as well as migrant Fulani) are allowed to use the dam, whether the dry season farmers are happy with their presence, and whether they prefer them to leave (see Table A3). 


\subsection{Research Methods}

The research was conducted through interviews and a survey over the period from November 2016 to July 2017. Qualitative data was gathered as most of the enabling conditions-such as group characteristics or the external institutional environment-are variables of a non-numerical nature. The interviews were conducted in a semi-structured manner to leave the respondent some space to inform the researcher about issues outside of the framework. A variety of research methods were employed to collect the qualitative data (see Table 1 below). Dam users (dry season farmers, Fulani pastoralists, livestock owners) and local authorities such as chiefs, landowners were targeted to collect data from because these were expected to have the most knowledge about dam usage and management. Additionally, to analyse the local institutional environment, regional government officials at the district assembly and NGO district directors were interviewed. Focus groups discussions were conducted with groups of APD users as this may trigger discussion and a larger number of respondents can be involved more efficiently. In the Northern Ghanaian context, women and Fulani pastoralists tend to be more informative when communicated with in a group setting with other women or pastoralists which is why also for them focus groups were organized.

Table 1. Overview of respondents per data collection method.

\begin{tabular}{|c|c|c|c|}
\hline Method & $\begin{array}{c}\text { Number of } \\
\text { Respondents/Sessions }\end{array}$ & Types and Number of Different Actors & $\begin{array}{l}\text { Gender Division } \\
\text { of Respondents }\end{array}$ \\
\hline \multirow{8}{*}{ Interviews } & \multirow{8}{*}{34} & \multirow{8}{*}{$\begin{array}{l}2 \text { local government officials } \\
1 \text { NGO district officer } \\
1 \text { chief } \\
4 \text { community unit committee members } \\
\text { (of which } 3 \text { also dry season farmers) } \\
12 \text { Fulani pastoralists } \\
5 \text { dry season farmers } \\
5 \text { land owners (of which } 3 \text { also livestock } \\
\text { owner) } \\
4 \text { livestock owners }\end{array}$} & 2 Male \\
\hline & & & Male \\
\hline & & & Male \\
\hline & & & 3 Male, 1 Female \\
\hline & & & 9 Male, 3 Female \\
\hline & & & 3 Male, 2 Female \\
\hline & & & 5 Male \\
\hline & & & 5 Male \\
\hline Focus Groups & 7 & $\begin{array}{l}5 \text { focus groups with dry season farmers } \\
2 \text { focus groups with Fulani pastoralists }\end{array}$ & $\begin{array}{l}32 \text { Male, } 12 \text { Female } \\
11 \text { Male }\end{array}$ \\
\hline Questionnaire & 175 & 175 dry season farmers & 91 Male, 84 Female \\
\hline $\begin{array}{l}\text { Participatory } \\
\text { observation }\end{array}$ & 1 session of 3 days & 1 Fulani pastoralist household & 2 Male, 1 Female \\
\hline
\end{tabular}

\section{Contextual Background: Agro-Pastoral Dams in the Upper West Region of Ghana}

The Upper West Region (UWR) in Northern Ghana is among the poorest and most sparsely populated areas in Ghana [29]. With around 700,000 inhabitants, the land is on average populated by 31 people per square kilometre and up to $70 \%$ of these people live below the poverty line of 1 dollar a day [29]. The rain water drains rapidly into the Black Volta, leaving the area without standing water bodies in the dry season when relative humidity is very low (Ghana Meteorological Department UWR, 2010). In these conditions, the region generally faces water stress for domestic and agricultural activities during the 7-month dry season. To improve water access during the dry season, the Government of Ghana and NGOs have been constructing APDs to promote dry season farming, animal watering and domestic uses [30]. In the UWR, a total of 84 dams and 54 dugouts exist and more are planned for construction [30].

The land, mostly used for subsistence farming and cattle grazing, is owned by families and clans at the community level, and the landlords are the 'custodians of the land' (Tendamba) who manage it on behalf of the family and clan members. The chiefs are the general overseers of the community, and together with the landlords responsible for permitting the arrival and settling of Fulani herdsmen within their jurisdiction. In general, these local authorities comprising chiefs, elders and Tendamba 
usually consent to the settlement of Fulani pastoralists. When the Ghanaians own the livestock and recruit Fulani to herd the cattle, these authorities are usually well informed with the arrival of the herdsmen. Sometimes however, livestock owners engage herdsmen without the knowledge of local authorities. In such an instance, the herdsmen only respect the livestock owner and view them as above anyone else in the village, while the chief imposes sanctions on them and would prefer them to leave. This can be challenging for the local authorities however, as livestock owners may have regional political connections or occupy regional governmental positions themselves [29,31].

With the first settlement of Fulani pastoralist in Northern Ghana as a response to the 1970s droughts, relationships with farmers were initially cordial and mutually beneficial. However shortly after the settlements some conflicts already erupted, and Fulani were blamed for crop destruction and livestock thefts $[7,31,32]$. More recently, scarcity of water (besides land) especially in the dry season has intensified the debate on pastoralism and their effects on water resources in the UWR. While there were several measures by the Upper West regional government to eject pastoralists as a way of resolving the rampant conflicts between pastoralists and farmers [8], pastoralists are still residing in the UWR and the conflict between them and other actors continue [29]. Tonah [8] argues that regional governments in the UWR are reluctant to take up the Fulani issue as they fear to displease the chiefs and other prominent persons that own cattle. Additionally, as discussed previously, some of the livestock owners that hire Fulani occupy government positions [29]. Around 2000, when the local government of the UWR set up a task force to regulate the activities of pastoralism and prosecute chiefs who allocate land to these pastoralists, the chiefs saw this as local government usurping their role on whom to allocate the land to [8]. Until today, chiefs and Tendamba continue to allocate land to Fulani pastoralists.

This study took place in a rural area within the recently merged Nadowli-Kaleo district in the UWR of roughly 450 square kilometres (see Figure 2). Multiple agricultural and agro-pastoral communities live here, as well as a pastoral minority group belonging to the Fulani ethnic group. 6 villages are studied that all have an APD, which are mainly used for irrigation of crops, livestock, and fishing. All of the dams are constructed during the 1990s and early 2000s by externally funded projects, mostly by NGOs and a few by the Ghanaian government. The 6 dam communities in the Nadowli-Kaleo district are taken as a case study for several reasons. One, all the communities have an agro-pastoral dam used by multiple user groups, which are mainly dry season farmers and pastoralists. Two, the dams have been constructed relatively recently by external actors. The studied dams should obviously be funded by external actors and not locally, because this research focuses on issues concerning APDs established by external interventions. Three, the 6 communities are chosen because these are beneficiary communities of future programming of the Adaptation Fund $(\mathrm{AF}$, an international fund that finances adaptation interventions set up under the United Nations Framework Convention on Climate Change (UNFCCC) as part of the 2005 Kyoto Protocol) of which one of the aims is to rehabilitate existing APDs in Northern Ghana. The researched dams are planned to be rehabilitatedby the AF interventions among the other activities listed the previous section within one or two years. These planned interventions will bring changes to common water abundance and perhaps management, therefore this research can feed into the implementation process of the AF and more future interventions likely to be implemented in Northern Ghana. 


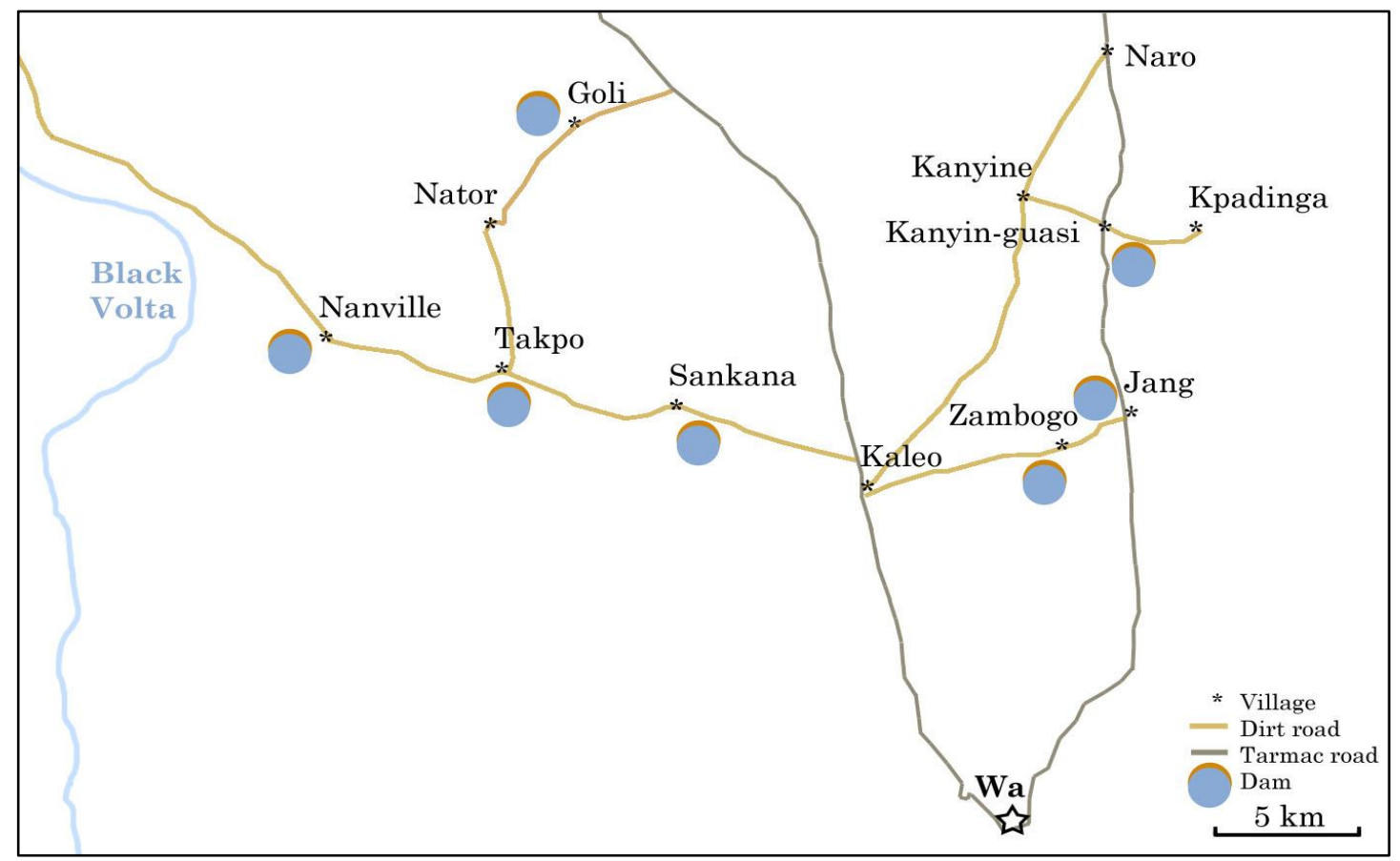

Figure 2. Map of study area (by author, based on Google Maps and fieldwork observations).

\section{Results}

\subsection{Collective Action Concerning the APDs}

\subsubsection{Resource Characteristics}

The enabling conditions for collective action are met for each APD concerning resource characteristics. All APDs serve 1-3 villages, where the size of the dam does not hinder potential for monitoring the users of the dam. The boundaries are also well defined, as for all the dams it is clear what water body exactly is the water belonging to the dam, and to what village the dam belongs.

\subsubsection{Group Characteristics}

Group size and clearly defined boundaries: Group sizes are small for all dams, as they range from 1-3 villages, with 5-80 dry season farmers and 1-15 pastoralists per dam. For dry season farmers, it is clearly defined who uses the dam and who does not. As the groups of farmers are relatively small, the farmers know each other generally well and know who cultivates a plot near the dam. For pastoralists, these group boundaries are less clear. Often, Fulani settled in villages without a dam drive the cattle to neighbouring villages where there is one.

Shared norms: These can be seen as an implicit or explicit agreement between dam users on how they should use it and who is allowed to use it, different types of dams can be characterised. In all the dams, users from outside the village where the dam is located use it, often from neighbouring villages. However, in some dams the users in the village where the dam is located allow this freely (Nanville, Jang, Takpo), and in other dams payments are requested by the hosting village (Kanyin-guasi and Goli) — which are usually not paid and the dam is used in secret early in the morning or in the night instead when there is no monitoring. These dam users therefore have no shared norms, as the outside villagers stated that they do not consider it ethical or 'fair' to request payment from them for using water. Simultaneously, they are aware that the dam users living near the dam would not resort to physically excluding them as this would be considered immoral.

Past successful experiences/social capital: Levels of social capital are mixed depending on dam user groups. Between dry season farmers, high levels of social capital (i.e., trust and a feeling of 
'togetherness' with each other) are generally there. They are usually from the same village and extended families and work together in their dry season gardens. Between livestock owners this is a similar story, as they divide their land into sections where they allow their hired Fulani to settle. Between livestock owners and the dry season farmers, social capital is not always high however. Some farmers blame the livestock owners for hiring 'irresponsible' and 'reckless' Fulani to drive their cattle. Many dry season farmer men reported of armed robbery (Goli) and farmer women of cases of rape (Takpo). Social capital between the settled Fulani (usually 2-4 families per dam-owning village) and the (dry season) farmers is therefore very low. They do not interact, and most see the hired Fulani as intruders that cannot be trusted. Social capital between (dry season) farmers and livestock owners has also been lowering when the first Fulani were hired as from around 2010 in most villages. Especially in Takpo social capital between dry season farmers, livestock owners and the Fulani is very low and there are cases of mutual aggression, as in 2016 all dry season farms around the dam were destroyed by cattle driven by Fulani children.

Appropriate leadership: this is seen as an important aspect for APD management by dam users in the villages. When asked for who is seen responsible for the dam, most farmers do consider local leaders elected for the dam/unit committees responsible for dam maintenance. Unit committees members are villagers elected to monitor the dam, alongside other activities which are mainly collecting taxes for the regional government and 'acting as policemen' as most of the villages do not have regular visits of police officers. Framed according to a trias-politica model, in local communities the unit committees are a form of executive power, where chiefs and elders (including the Tendamba and Tindeme) are the local legislative and judicial powers alongside the regional court. The unit committees are therefore not seen as 'powerful' themselves by other community members, or as they call it, as 'big men'. Judging by the wealth of unit committee members, this highly varies from illiterate elders in Nanville to literate and English-speaking youngsters in Jang.

Smaller groups think the dam is the responsibility of the local landowners (Tindeme) on whose land the dam is located or see themselves as most responsible or the local government (see Table 2). This means that 9 out of 10 farmers do not see themselves responsible for dam maintenance, and think local leaders-mostly committee members and landowners-are the ones that have responsibility for dam maintenance. But to what extent is such leadership 'appropriate'? According to commons theory the leadership is considered appropriate when the local leaders are 'familiar with changing external environment and connected to local traditional elite' [11]. In every village, in its traditional hierarchical structure, there were always people seen as local leaders, usually the group of chiefs, Tendamba (the 'custodian of the land'), tindeme (landowners), and the few relatively wealthy livestock owners. However, most villages these leaders were not actively involved in management of the dams. These local elites mostly thought that local governments and NGOs should help them out with dam rehabilitation as they lacked the funds. The elected dam/unit committee members did often not belong to the local elite group, while they are seen as responsible for dam management by the users. The committee members were to different degrees involved in dam management, and organized 'communal labour' in all of the communities to maintain and rebuild the dam in the past. All of them admitted that this was not enough to maintain the dam in the state it was in the first years after construction by NGOs and the local government. Their connections with the local elites did often not appear strong, as most unit committee members said they did not belong to the local leadership nor did they listen to them. Leadership is therefore not appropriate in most villages. 
Table 2. Persons/institutions responsible for APD maintenance according to the surveyed dry season farmers.

\begin{tabular}{cc}
\hline $\begin{array}{c}\text { Persons/Institutions Seen as } \\
\text { Responsible for APD Maintenance }\end{array}$ & $\begin{array}{c}\text { Number of Dry Season Farmers that } \\
\text { Think Responsibility Lies with }\end{array}$ \\
\hline Local government & $6(3 \%)$ \\
NGO & $2(1 \%)$ \\
Unit/dam committee & $104(59 \%)$ \\
Dry season farmers & $15(9 \%)$ \\
Landowners & $32(18 \%)$ \\
Missing & $16(9 \%)$ \\
Total & $175(100 \%)$ \\
\hline
\end{tabular}

Interdependence among group members: Interdependence among group members related to dam usage is low in all the villages. The irrigation systems constructed by NGOs would initially have lifted interdependence among the dry season farmers as the functioning of the furrows would affect all the farmers. This was not enough of a trigger to maintain such furrows however, as the pipeline under the dams mostly stopped supplying water due to the silting of the dam or water levels that became too low. When such water supply stopped functioning (usually within 3 years after dam construction) the farmers resorted to using buckets in order to water their plot. The buckets are either directly filled in the dam and carried to the plots, but in order to reduce labour intensity most farmers now dug shallow wells behind the dam next to their plots to fill their buckets, using the high water table. Nearly all farmers (95\%) use buckets to water their plots, while the remaining 5\% uses pumps and pipelines. Using the dam directly or shallow wells lowers interdependence among farmers, as they only need to maintain/redug shallow wells usually used by $3-5$ farmers instead of collective irrigation furrows used by all the farmers. Despite that the farmers do not use collective irrigation systems, some interdependence remains as all rely on the same body of water-including livestock owners and fishermen.

Heterogeneity of endowments: This basically means differences in economic assets between dam users, however most commons researchers specify this towards differences in access to the resource by the users. Generally, water access between dry season farmers is not very different, as almost all use buckets to water their plots directly from the dam or from shallow wells in the irrigable area. The dry season farmers using an APD nearly always reside within the nearby village territory, located from a few hundred meters up to a few kilometres away. Most live within walking distance to the dams, while some use bicycles (mostly men) (see Tables 3 and 4 )

Table 3. Time it takes for dry season farmer to reach the village APD.

\begin{tabular}{ccc}
\hline Time it Takes to Reach the Dam & No. of Dry Season Farmers & Gender Division \\
\hline Up to $15 \mathrm{~min}$ & $114(65 \%)$ & 57 women, 57 men \\
Up to $30 \mathrm{~min}$ & $49(28 \%)$ & 22 women, 27 men \\
Up to $1 \mathrm{~h}$ & $12(7 \%)$ & 5 women, 7 men \\
\hline
\end{tabular}

Table 4. Modes of transport of dry season farmers to reach the village APD.

\begin{tabular}{ccc}
\hline Mode of Transport to the Dam & No of Dry Season Farmers & Gender Division \\
\hline On foot & $150(86 \%)$ & 82 women, 68 men \\
Bicycle & $21(12 \%)$ & 1 woman, 20 men \\
Motorbike & $3(2 \%)$ & 0 women, 3 men \\
\hline
\end{tabular}

Considering heterogeneity in water access for the Fulani pastoralists, the differences between Fulani pastoralists are high, as some live in a village where a functioning APD is situated whereas others need to travel to other villages with dams in order to access water. 
Pastoral and agricultural water uses of the APD differ highly and are less straightforward to compare, however most dam users think livestock owners benefit most from the dams. When looking at the broader definition of endowments, meaning economic assets, considerable differences are also clearly within the dry season farmers. While actual wealth has not been measured in the survey, education levels and number of widows provide a proxy indication. Most of the dry season farmers have not attended any education, and twice the number of men have attended high school or more tertiary education compared to women (see Table 5).

Table 5. Education levels of dry season farmers.

\begin{tabular}{ccc}
\hline Education Levels & No of Dry Season Farmers & Gender Division \\
\hline None & $126(72 \%)$ & 66 women, 60 men \\
Primary School & $16(9 \%)$ & 7 woman, 9 men \\
High School & $29(17 \%)$ & 10 women, 19 men \\
Tertiary education & $3(2 \%)$ & 0 women, 3 men \\
\hline
\end{tabular}

Interestingly, a gender division can be seen favouring women for chemical fertiliser. Slightly less than half of the total dry season farmers use chemical fertiliser, and of those who use it are a majority women (see Table 6) - because more than a third of them are widows who are involved in NGO programming for dry season farming.

Table 6. Usage of chemical fertiliser by the dry season farmers.

\begin{tabular}{ccc}
\hline & No of Dry Season Farmers & Gender Division \\
\hline Uses chemical fertilizer & $76(43 \%)$ & 45 women, 31 men \\
Does not use chemical fertiliser & $99(57 \%)$ & 39 woman, 60 men \\
\hline
\end{tabular}

Homogeneity of identities and interests: Identities, which the dam users define mostly as 'tribe and community membership', are similar for the dry season farmers and livestock owners as they mostly are from the same villages and are often related to each other through family lines. The Fulani however, hired to 'take care' of the cattle of livestock owners, are seen by the farmers as strangers and intruders having different cultural values. In the villages of Jang, Takpo and Goli farmers see the Fulani sometimes as criminals, and accuse them for stealing poultry, armed robberies and even of rape of women. In Jang and Takpo, farmers complained that the Fulani are a hindrance to their dry season farming activities, because their self-made wooden fences are not strong enough to keep the cattle out. The interviewed Fulani pastoralists often showed understanding that they are seen as intruders and strangers, with their ethical and cultural roots from north of the Ghanaian border. As such, they "live by themselves" and do not attempt to intermingle with the villagers, while they are settled on the brinks of community borders in the bush. Most of the Fulani are only settled 1-5 years, and speak a language different to the communities they settle in. Altogether, homogeneity of identities and interests are therefore low.

\subsubsection{Relationship between Resource System Characteristics and Group Characteristics}

Overlap between resource user's residential location and the resource location: As said previously, basically all (93\%) of the dry season farmers live in the village from walking distance of the dam, as well as the Fulani pastoralists living on the brinks of the villages. However, most of the dams are also used by Fulani pastoralists settled in villages without dams, located usually up to one day of walking from the dams (approx. 12 kilometres maximum). All the movements of the Fulani pastoralists are mapped out below (see Figure 3). Also Fulani from neighbouring districts where no dams have been constructed come in and use the dams during the dry season. The assumption of the enabling conditions that this has a negative influence on collective action is demonstrated by the village of Jang. 
While they are generally happy with the useful herding of their cattle by the Fulani settled in their community (see Section 5.2.2, Figures 5 and 6), they complain about the Fulani coming in from Wa East as "they do not know the chiefs and landowners good enough to make arrangements with".

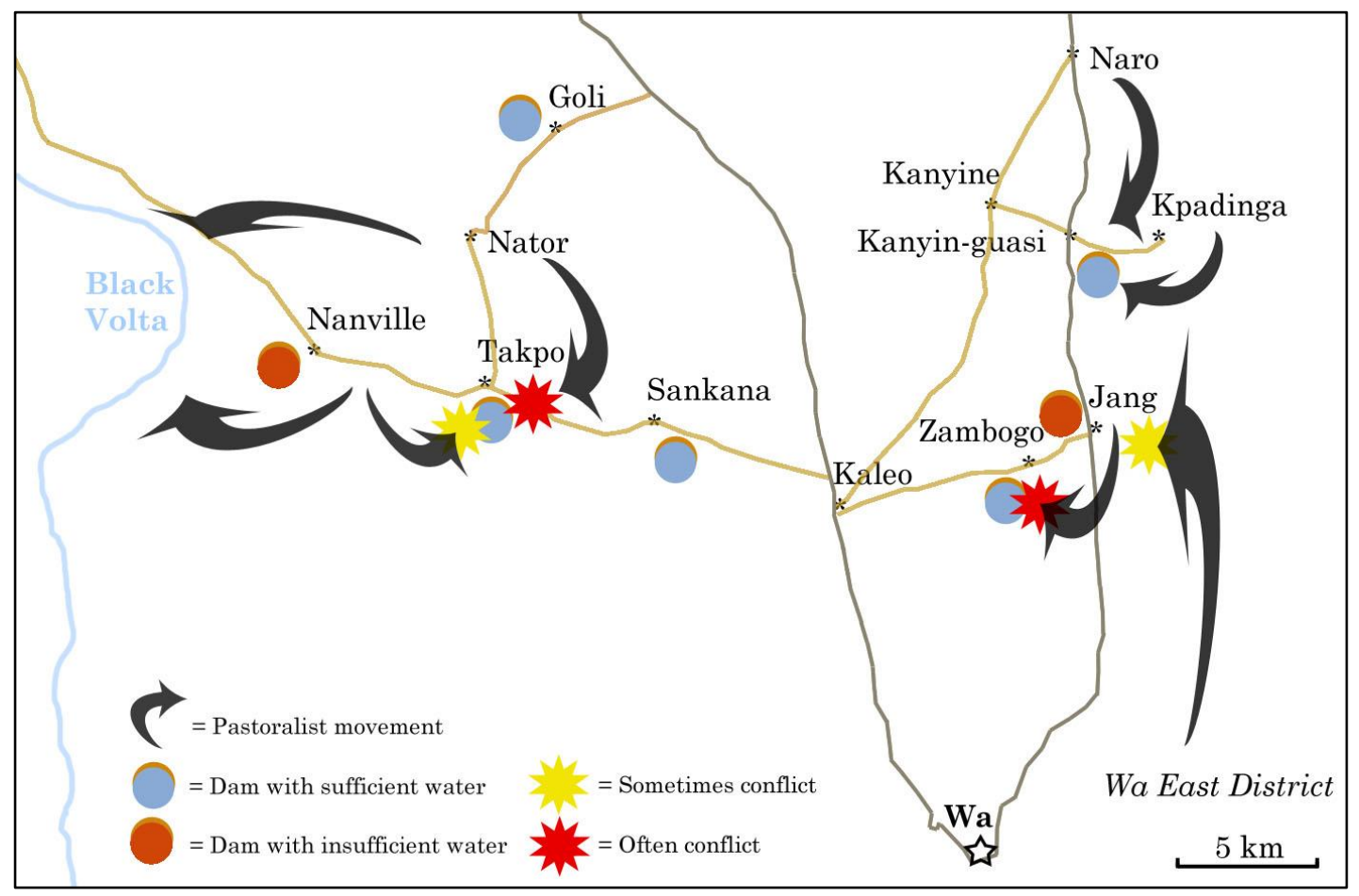

Figure 3. Map on Fulani pastoralist movement and conflict-prone areas with farmers during the dry season (map by author, based on Google Maps).

Levels of dependence on the resource system: Levels of dependence vary strongly between dam users. Within the group of dry season farmers, it became clear during the interviews that some completely depend on the dam to maintain their livelihood, especially widowed women lacking agricultural income during the rainy season. As widowed women are a relatively large group in the total group of farmers (30 out of 175 farmers, not incorporating widowed men), this lifts the general level of dependence on the dam. On the other hand, other farmer men mainly see an interest in the dam to grow cash crops, such as sugarcane in Jang. They therefore also easily give up farming, including maintenance of the shallow wells and the dam, when it is too labour intensive and not profitable enough - contrary to the widowed women whose food supply relies on dry season farming. Livestock owners and the Fulani pastoralists also highly depend on the dams, however they have more 'escape options' if a dam stops functioning - they are mobile enough to bring cattle to another neighbouring dam that still functions.

\subsubsection{Institutional Arrangements}

Fairness of allocation of dam benefits: According to the dry season farmers, the benefits of the dam are distributed fair (174 out of 175), pointing towards a high fairness in allocated dam benefits. However, they do not consider it unfair if some benefit more than others. When asked who benefit most from the dam, most dry season farmers said that the relatively wealthy livestock owners benefit most because they can utilize the dam effectively to raise their cattle numbers within a few years. Also most of the interviewed livestock owners themselves admitted this, as the dry season farmers have not able to utilize the water for irrigation as intensively. So even though the dam users consider the distribution of dam benefits fair, defining fairness as an equitable distribution of benefits, it cannot be considered as such. 
Rules are simple and easy to understand: Complexity of rules is currently not an issue because complex rules do not exist concerning the dams. The few existing rules are mainly set up by the local chiefs and landowners in response to incidents, such as restricting Fulani to let cattle graze near dry season farms (Goli) or demanding contributions of livestock owners to dam maintenance (Kanyin-guasi).

Locally devised access and management rules: Locally devised access and management rules differ per village. As just noted, only in Goli and Kanyin-guasi there are some rules on dam access and management, such as areas of irrigable land restricted for livestock access and maintenance payments based on cattle ownership. For all dams, permission of the person owning the land where the dam is situated is needed in order to start a dry season plot, which under normal circumstances is given to anyone from the respective village. Also some rules exist on where plots can be located, primarily locating them downstream of the dam instead of upstream, as upstream plots are harder to irrigate and may release chemicals into the dam's water reservoir. This rule and rules on which pastoralists can access the dam are locally devised and enforced in some villages—again in Goli and Kanyin-guasi-but not in others (Zambogo, Nanville, Jang, Takpo).

Ease in enforcement of rules: Enforcement of rules is strongly based upon local beliefs, especially 'curses'. A farmer in Jang explained: “Last year we ran out of water, because someone opened the irrigation pipe during the rainy season. When we realized and closed it, the rainy season was almost over. Someone did it to fish the water, someone from the community around the dam. They could not find the person, and the Tendamba cursed him. If the person does it again, it should not survive". The generally strong belief in the effect of curses can help in enforcing rules and preventing offenders to break rules again. However, applying such a curse affect Fulani pastoralists less, because they do not adhere the same customary beliefs. An important rule in all the villages is that a livestock owner should compensate for the costs concerned if his cattle has destroyed crops of a farmer. Compensation can be paid in money, crops, or animals. Crop destruction is a widespread problem, as over a third of the surveyed farmers had their crops destroyed in the last few years (61 out of 175). Of these people, nearly all (57 out of 61) stated that they were not given sufficient compensation. When asked about this problem, they stated that crops often get destroyed either by family members who cannot afford to pay them compensation, or by Fulani cattle who refuse to admit that it was their cattle that destroyed it. Enforcing such a rule therefore hardly happens in the studied area.

Graduated Sanctions: Graduated sanctions are absent in most villages, and sanctions are as said limited to applying a curse.

Availability of low cost adjudication: While there is no official police presence in the villages, Traditional local and governmental regional low cost adjudication are present in all the villages. For every village, the chief and Tendamba possess the authority to sanction people for deeds strongly considered as crimes such as stealing, adultery (for women) and rape. The elected unit committee members are seen as 'voluntary policemen'. However, the dry season farmers, livestock owners and Fulani pastoralists complained about the strong biases and weak enforcement of both formal national law and local bylaws. The chief in Takpo is having difficulty enforcing bylaws through the unit committee as these are easily bribed.

Also the Fulani pastoralists complained about the insecurity of their stay because the livestock and land owners may expel them anytime based on accusations-whether true or false. The livestock owners protect them to threats from the villages to a certain extent and their relationships are mostly cordial. However if a group of villagers accuse the Fulani of for example destroying crops or theft of poultry they may be expelled by the Tendamba. According to some of the Fulani, their livestock owner mostly chooses 'the side of the community', as the Fulani can easily be replaced for another family when they are blamed for anything by the villages they are hosted by.

The dry season farmers on the other hand, complain about the corruptible state-led adjudication in the form of regional police based in Nadowli, who are easily bribed by wealthy cattle-owning Fulani settlers. In general, and as a response of the corruptible police, the villagers prefer the chiefs to resolve 
conflict. According to a Jang unit committee member, the court is strongly biased towards those who have political connections with the local government. Forms of adjudication are present, through local courts with the chief and Tendamba or at the regional police station. However, the courts seem not to be neutral and easily corruptible, either or both through political connections or bribes.

\subsubsection{Relationship between Resource System and Institutional Arrangements}

Accountability of monitors and other officials to users: The ones mostly seen as responsible by the dry season farmers for monitoring the dams are the unit committees (see Section 5.1.2, Table 2). In most villages, accountability appeared to be low as most committee members did not do basic tasks such as paying regularly visits to the dam nor had clear ideas on how many people actually use the dam. A dry season farmer stated:

"In principle we have the 'dam rehabilitation committee', a 'water use association', 'fishermen association' and an 'irrigation committee', but not in practice. These were put in place and elected with the construction of the dam. Every section was assigned to a man and a woman to be representing their section in the committees. The committee people are supposed to be monitoring the dam, but they don't operate."

Restriction on harvest to match regeneration of the resource: Water use and inflow rates are not clearly matched for any of the dams. None of the unit committees have knowledge on the carrying capacity of the dams, however they do have rough ideas on what water levels should be at the onset of the dry season in order for them to take it through the season. As there are no ideas on how many farming plots/cattle can use the dam, harvests are not restricted to the regeneration rate of water levels during the rainy season. This however does not mean that the water is automatically overused in the studied dams. On the contrary, most water levels remain rather high —with the exception of Jang and Nanville-and is usually sufficient for the dry season farmers and pastoralists using it.

Low cost exclusion technology: The best available form of exclusion technology from using dams and surrounding land for farming or grazing are fences. While none of the dams are fenced, most of the dry season farmers fenced their plots in order to prevent livestock from grazing on it. Most of the fences are made of wood by the farmers themselves while others have iron fences provided by NGOs or the local government (see Table 7 below).

Table 7. Fencing technologies used by dry season farmers.

\begin{tabular}{cccc}
\hline $\begin{array}{c}\text { Method of Farming } \\
\text { Plot Protection }\end{array}$ & $\begin{array}{c}\text { No. of Dry Season } \\
\text { Farmers }\end{array}$ & Fence Made/Provided by & $\begin{array}{c}\text { Gender Division of } \\
\text { Respondents }\end{array}$ \\
\hline No Fence & $21(12 \%)$ & - & 11 women, 10 men \\
\hline Wood & $91(52 \%)$ & $\begin{array}{c}83 \text { farmer themselves, } \\
8 \text { family members }\end{array}$ & 35 women, 56 men \\
\hline Plants & $1(1 \%)$ & 1 farmer husband & 1 woman \\
\hline Iron & $62(35 \%)$ & 59 NGO, 3 farmers themselves & 37 women, 25 men \\
\hline Total & $175(100 \%)$ & $\begin{array}{r}86 \text { farmers themselves, } \\
\text { family members, 59 NGO }\end{array}$ & 84 women, 91 men \\
\hline
\end{tabular}

The wooden fences are the cheapest and most accessible form of exclusion technology, but these function often not very well as they are prone to catch fire, degrade or destroyed by hungry cattle as happened in Takpo and Jang, leading to the demise of most dry season farming activities. Iron fences, which are generally more efficient in keeping cattle out are very costly for the farmers and they generally can not afford it (only 2 out of 175 surveyed farmers purchased their own iron fence). Interestingly, women tend to have an iron fence from an NGO more often than the men, because these are recipient to NGO projects targeted at widowed women in Goli and Nanville. 
Local authority is not undermined by central government: All interviewed chiefs and landowners confirm that they have the authority to locally manage the land and water resources, including dams, according to their will.

\subsubsection{External Environment}

Presence of supportive external sanctioning institutions: External sanctioning institutions are strongly related to the previously made point on availability of low cost adjudication (Section 5.1.4). The regional police office and court are the external sanctioning institutions, but according to all the different dam users these are easily corruptible through bribes (money or cattle) and political connections. It is therefore clear that there are no supportive external sanctioning institutions present.

Appropriate levels of external aid to compensate local users for conservation activities: This condition can be contextually translated as aid given by the local government and NGOs to dam maintenance conserving the water levels and perhaps fish and crocodile populations in the dams. Only in Takpo the NGO that funded the dam construction (GIZ) also provided help in rehabilitation and reconstruction of the dams several years later. In the other villages, dam rehabilitation has been organized by the dam users themselves from the late 2000s up to now. No support to any of the villages has been given to conserve water, fish and crocodile populations. Therefore, external aid has in general been very low after dam construction, which is why it is plausible to assume that levels of external aid have not been 'appropriate'.

Nested levels of appropriation, provision, enforcement and governance: There are no signs that the limited number of local institutional arrangements are nested in higher levels of governance. Interviewed regional government officials indicated that the dams are 'left to be managed by the community' and stated that they lack the resources to undertake maintenance themselves. The interests of the community-scale authorities (chiefs, Tendamba) including pastoral dam use are supposedly nested into inter-communal institutional bodies, which is the regional paramount chief. However, the role of not only the regional government, but also the paramount chief concerning resource management of communities appears to be limited: In 2015, the paramount chief in collaboration with the regional government have made many calls to send out settled Fulani. None of the studied communities have listened to these calls. This both points towards a strong devolution in power and the limited influence of inter-community governance levels on dam and other resource arrangements. Considering nesting of arrangements of dry season farmers on the community scale, only in Goli representatives of different irrigation sections are organized in an irrigation committee. Pastoral dam usage is also not nested in any level above that of the landlords and chiefs they are hosted by. While they often use pasture and water in neighbouring communities (see Figure 3 in Section 5.1.3), no successful arrangements tend to be made on an inter-communal scale.

\subsection{Inclusivity of the APDs}

\subsubsection{Dry Season Farming: A Necessity for the Poor, or a Hobby for the Rich?}

Dry season farmers: numbers and crop usage: Only small groups of people in the communities do dry season farming. Ranging from 21 to 60 households, the dry season farmers are estimated to range from only $8 \%$ up to $31 \%$ of every studied community. While the number of household per community highly differ, from 625 in Takpo to around 80 in Kanyin-guasi, the number of dry season farmers per community are less diverse (from 21 to 60 households, visualised in Figure 4). 


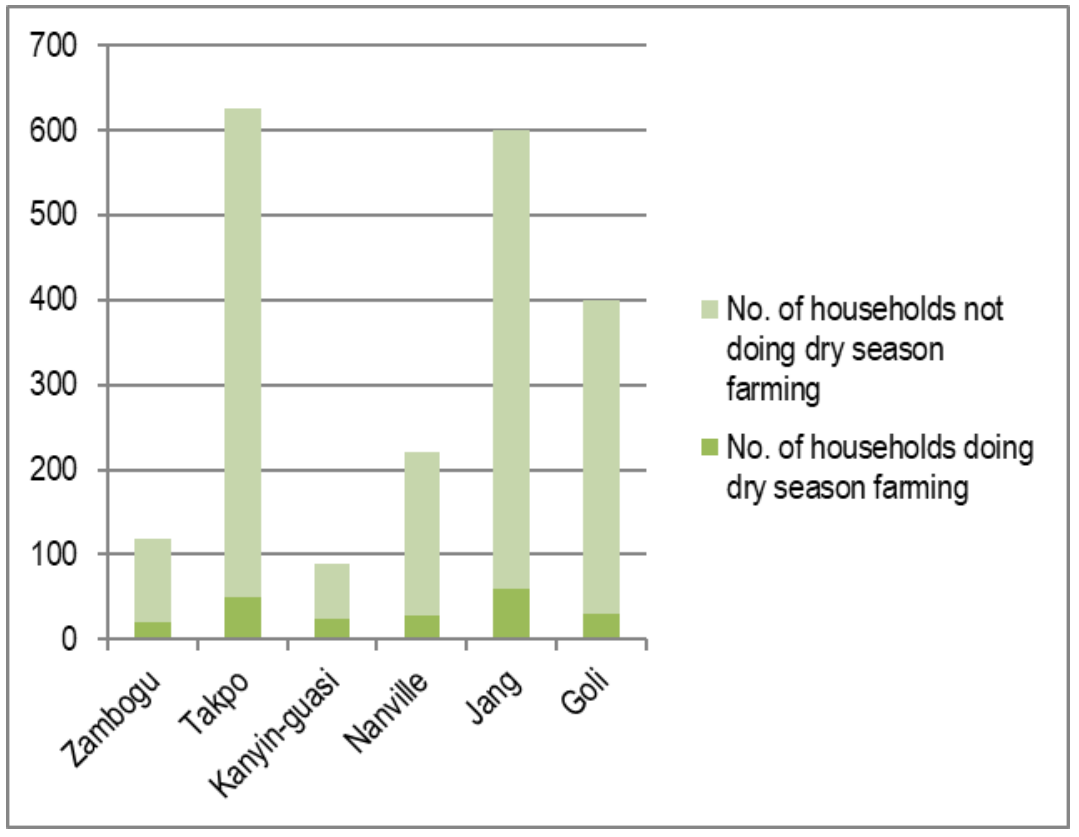

Figure 4. Absolute number of household heads and dry season farming household per community.

While there is no quantitative data on the number of livestock owners using the APDs, it appears from the village visits that their numbers range from 5 to 20 per community. All of the surveyed farmers sell their crops at the market in their or in a neighbouring community. Therefore, none of the surveyed dry season farmers solely use the crops directly for their own food needs. The widowed women however (more than one third of the surveyed dry season farming women) indicated in a focus group discussion they directly rely on selling the dry season crops to buy other food stocks.

Socio-economic diversity of the dry season farmers: The third result compares the share of dry season farmers that use chemical fertiliser to the distribution of wealth in the respective community. CARE's Adaptation Learning Programme (ALP) has made a useful assessment of household numbers and economic wealth of three of the studied villages-Zambogo, Takpo and Nanville-which are used in this analysis. Very poor are defined by ALP as not being able to afford basic needs and rely on others for food. Poor means having only one meal a day, inadequate housing, small food stocks and education up to junior high school. Middle means having sufficient food, use chemical fertiliser for farming, electricity, brick housing, owning some animals, a radio, and often a motorbike. Rich means having adequate food surplus all year, own cattle usually up to 10 and at least a five-acre farm for which they use chemical fertiliser and hire a tractor to plough. The assumption here is that a farmer can be considered poor if he/she does not use chemical fertiliser for (dry season) farming. According to ALP, chemical fertiliser generally cannot be afforded by the (very) poor dry season farmers, but can by their 'middle' and rich colleagues [33]. Comparing the share of 'very poor' and 'poor' to the share of 'middle' and 'rich' in these villages to the estimated number of dry season farmers that use chemical fertiliser provides an insight on socio-economic inclusivity of their dams. The distribution of wealth per village for the 3 villages ALP [33] provided data on is displayed below (Table 8). The other three villages for which there is no ALP data on (Kanyin-guasi, Jang and Goli) division of wealth has been roughly estimated. The average results of the three villages for which there is ALP data has been extrapolated for these villages. 
Table 8. Number and share of very poor, poor, middle and rich households in three of the studied villages (based on ALP [33] data).

\begin{tabular}{cccccc}
\hline Village & $\begin{array}{c}\text { No. of } \\
\text { Households }\end{array}$ & $\begin{array}{c}\text { No. of 'Very } \\
\text { Poor' }\end{array}$ & No. of 'Poor' & $\begin{array}{c}\text { No. of } \\
\text { 'Middle' }\end{array}$ & No. of 'Rich' \\
\hline $\begin{array}{c}\text { Zambogo } \\
\text { Takpo }\end{array}$ & 118 & $20(17 \%)$ & $41(34 \%)$ & $29(25 \%)$ & $28(24 \%)$ \\
Nanville & 625 & \multicolumn{2}{c}{$500(80 \%)$} & $120(19 \%)$ & $5(1 \%)$ \\
Kanyin-guasi & 220 & $38(17 \%)$ & $50(23 \%)$ & $110(50 \%)$ & $22(10 \%)$ \\
Jang & Est. 80 & Est. $20 \%$ & Est. 38\% & Est. $30 \%$ & Est. $12 \%$ \\
Goli & Est. 600 & Est. $20 \%$ & Est. 38\% & Est. 30\% & Est. $12 \%$ \\
& Est. 400 & Est. $20 \%$ & Est. 38\% & Est. 30\% & Est. 12\% \\
\hline
\end{tabular}

The number of farmers that use chemical fertiliser is the indicator to be compared to the wealth distribution of the communities above. As those farmers that use chemical fertiliser are assumed not to be (very) poor, the socio-economic diversity of the dry season farmers is then determined to be low, moderate or high. The discussed results and the estimates for the villages lacking data on are displayed below (Table 9)

Table 9. Number and share of dry season farmers using chemical fertiliser and socio-economic diversity of the dry season farmers.

\begin{tabular}{ccc}
\hline Village & $\begin{array}{c}\text { No. of Dry Season Farmers } \\
\text { Using Chemical Fertilizer }\end{array}$ & $\begin{array}{c}\text { Socio-Economic Diversity } \\
\text { of Farmers }\end{array}$ \\
\hline Zambogo & 9 out of $21(43 \%)$ & High \\
Takpo & 16 out of $29(55 \%)$ & Low (mainly rich) \\
Kanyin-guasi & 8 out of $25(32 \%)$ & High \\
Nanville & 2 out of $28(7 \%)$ & Moderate (mainly poor) \\
Jang & 19 out of $25(76 \%)$ & Moderate (mainly rich) \\
Goli & 20 out of $28(71 \%)$ & High \\
\hline
\end{tabular}

\subsubsection{Fulani Pastoralists: Exploited Tenants or Bribing Free Riders?}

Settled Fulani households and cattle ownership: It appears that all the Fulani families settled in the villages with dams and neighboring villages are allowed to own 10 or more cattle (with the recent exception of Goli and Nator). In Goli, cattle-owning Fulani have been expelled and replaced with non-cattle owning Fulani around 2014 due to crop destruction and land degradation according to the dry season farmers. Most of the Fulani households are allowed to own medium (up to 80 cows) cattle herds, which they do (18 out of 23 interviewed Fulani households owning between 5 up to 80 cows). This does not mean that these Fulani households are all wealthy however, as around half of the interviewed households own only a few cattle, and stated they have no money or desire to send their children to school, and have insufficient access to food. The other half can be considered middle-income or rich, as they have sufficient access to food, own more than 10 cattle and sometimes a motorbike. Poverty is not the cause for Fulani children not to go to school however, as they are expected to rear the cattle, also within wealthier households.

Fulani resource use and cross-communal movement: Generally, Fulani that rear their cattle and that of livestock owners are free to use the dams in the whole studied area. Not only because the water is generally abundant, but also because it is socio-culturally unacceptable for many dam users to exclude one's access to water. The Nanville unit committee chair summarized this cultural view by saying that "every living thing must take water ... even if they [Fulani] would destroy farms and empty the dam, we would never exclude anyone because God would not be happy". While this cultural values of cross-communal ownership of water may count in principle, in reality accessing dams in places outside of the hosting village territory can be challenging for the Fulani as they encounter dry season farmers aggressively guarding their farms. Most of the dry season farmers state that their aggressive stance is needed because Fulani are 'careless for their farms, and only care for the cattle'. The Fulani on the other hand 
complain that the farmers are often violent and sometimes wound their cows while they do their utter best to keep the animals off the farms. It was observed that cattle numbers are often too high to keep them completely under control when driving them through the narrow corridors in between the farms, where Fulani boys often have responsibility over up to 50 cattle each. The Fulani also stated that both the dry and rainy season farming areas are growing, making preventing crop damage more difficult and pasture more scarce. The areal growth in farming land was confirmed by all the other interviewed actors.

Dry season farmers usually have conflicts with Fulani coming in from outside their village territory to use the APD during the dry season, rather than with Fulani settled in their village. Only minorities experienced conflicts with settled Fulani (see Table 10). Common Fulani pastoralist movement during the dry season and areas of conflict are mapped out, indicating the frequency of conflicts that occurred the last 5 years (see Figure 3). Conflicts mean that violence occurs between the two APD user groups, and is usually caused by crop destruction. Two villages have acted to avoid conflict in the future: In Goli, having a dry season farmer belonging to the local elite, Fulani from outside the village territory (Nator) are restricted to enter the area. In Kanyin-guasi, cattle corridors have been assigned and livestock owners in neighbouring village (Kpadinga) have been requested to contribute money for dam maintenance (with little success at the time of the research).

Table 10. Number of dry season farmers that had a conflict with the settled Fulani in their community.

\begin{tabular}{cc}
\hline Village & No. of Farmers Who Had a Conflict with Settled Fulani \\
\hline Zambogo & 9 out of $21(43 \%)$ \\
Takpo & 7 out of $29(24 \%)$ \\
Kanyin-guasi & 1 out of $25(4 \%)$ \\
Nanville & 2 out of $28(7 \%)$ \\
Jang & 3 out of $25(12 \%)$ \\
Goli & 9 out of $28(32 \%)$ \\
\hline
\end{tabular}

Community perceptions of Fulani: Fulani are often seen as 'strangers' by the villagers because they are not Ghanaian, and are also often blamed for criminal activities. While free to use the APD in their hosting village, they are seen as hired outsiders, and are in no way included in dam management or maintenance. The interviewed Fulani generally understand and accept that role as the land on which they reside is not their 'native' land and have generally only settled down from 1 up to 10 years. The Fulani are also not involved in dry season farming activities. Dry season farmers say they do not involve them because 'it is not their culture, they are pastoralists, they only care about their cattle'. According to some of the Fulani they would not be reluctant to be involved, but that they do not have the desire to make investments in farming because of their insecurity of permanent stay: they may be sent out when they are no longer wanted by the village or when they decide find pasture elsewhere (usually further south into central Ghana). Making place-bound long term investment needed for (dry season) farming is therefore too risky. Some of the Fulani women do grow edible ('green' or 'bean') leaves around their compounds. Usually, the Fulani are given land around the compounds and kraals to do to rain-fed maize farming for subsistence, and the livestock owner hosting them often helps with ploughing and weeding, as well as provides them with seeds.

While the livestock owner relations with Fulani pastoralist are usually cordial and cooperative, the surveyed farmers have a negative perception of the Fulani settlers in their communities. Most of the dry season farmers in the studied villages are not happy with the presence of Fulani pastoralists and want them to leave their community, with the exception of Jang and Kanyin-guasi (see Figures 5 and 6 below). 


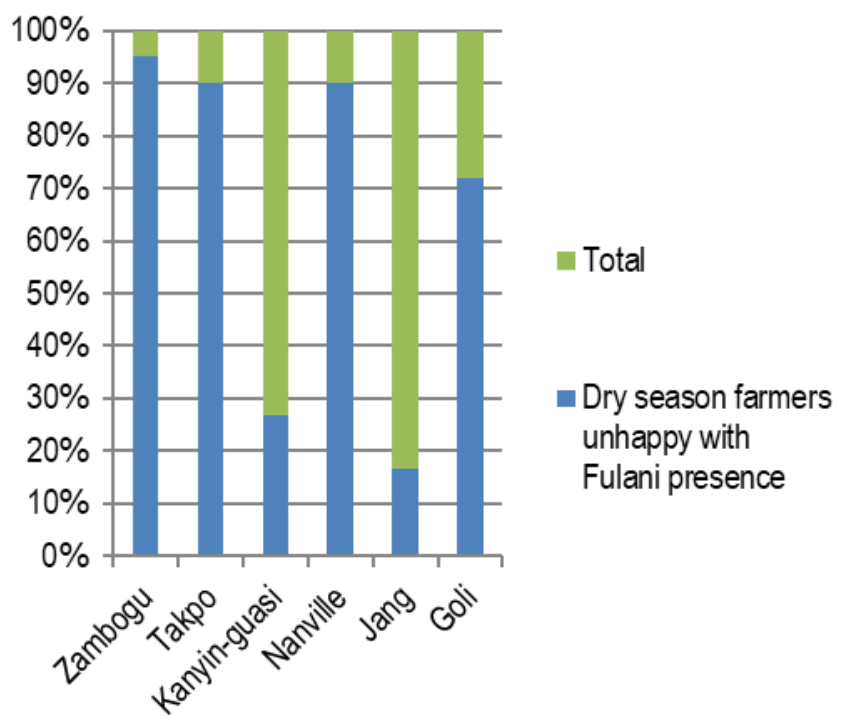

Figure 5. Share of dry season farmers that is unhappy with the Fulani settled in their community.

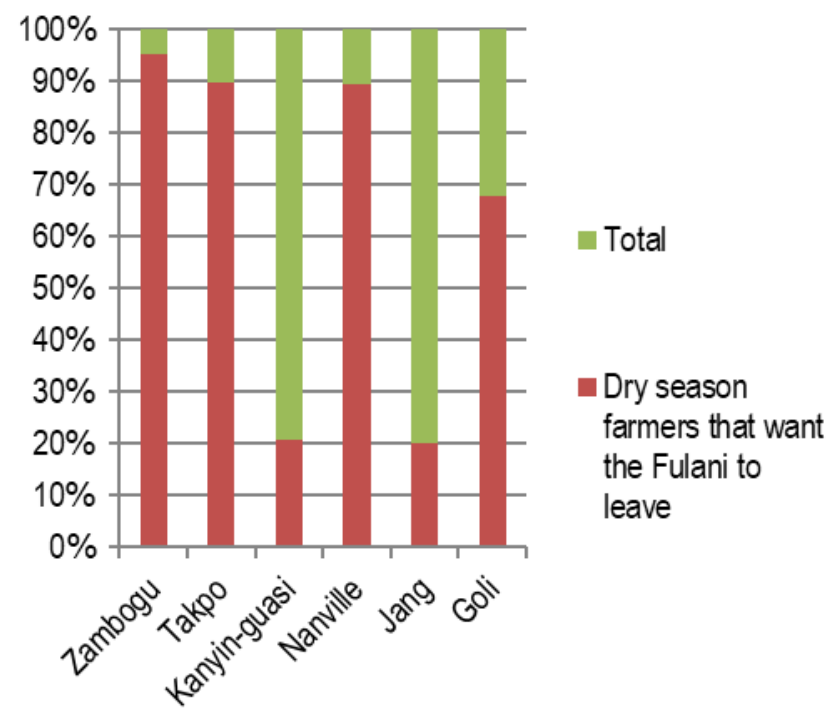

Figure 6. Share of dry season farmers that want the Fulani settled in their community to leave.

The main reason for discontent with Fulani presence is crop destruction. Nearly all of the farmers experience crop destruction by cattle reared by Fulani, which is why they are unhappy with their presence (see Table 11). Only some of them also dislike them because they think the Fulani are criminal in general:

Table 11. Number of dry season farmers that are unhappy with Fulani presence because crops got destroyed or because they perceive Fulani as criminals in general.

\begin{tabular}{ccc}
\hline Village & $\begin{array}{c}\text { No. of Farmers Unhappy with Fulani } \\
\text { Presence Because Crops Got Destroyed }\end{array}$ & $\begin{array}{c}\text { No. of Farmers Unhappy with Fulani Presence } \\
\text { Because They are 'Criminals in General' }\end{array}$ \\
\hline Zambogo & 21 out of $21(100 \%)$ & 3 out of $21(14 \%)$ \\
Takpo & 26 out of $27(96 \%)$ & 3 out of $27(11 \%)$ \\
Kanyin-guasi & 7 out of $7(100 \%)$ & 1 out of $7(14 \%)$ \\
Nanville & 23 out of $27(85 \%)$ & 10 out of $27(37 \%)$ \\
Jang & 4 out of $4(100 \%)$ & 1 out of $4(25 \%)$ \\
Goli & 22 out of $23(96 \%)$ & 2 out of $23(9 \%)$ \\
\hline
\end{tabular}


The results of discontent on Fulani presence are roughly in line with the number of farmers that actually experienced a conflict with the settled Fulani (Table 10). Apart from crop damage resulting in conflict and general stigmatisation, it became clear from the focus group discussions that the negative stance of farmers is also motivated by accusations that Fulani use resources unsustainably. Farmers blame Fulani for grazing in the night leading to overgrazing, cutting economic trees for their cows to eat, and carelessness about damaging farm plots, and do so because they can just leave somewhere else when the land or water sources are degraded. While livestock owners that contract the Fulani are responsible for their presence, the aggressive stance of the farmers is not directed towards these relatively powerful people. They know they usually do not have the power to demand from them to stop hiring the Fulani. Indeed, in most villages, the concentration of power to allow a Fulani household to stay lies with the local elites-chief, Tendamba and landowners. These local authorities can decide collectively whether a Fulani family is hosted, sacked or replaced. Excluding Fulani is therefore not a matter to decide for the common men and women, but for land- and livestock owners. In two villages there is much less discontent about the Fulani presence (Jang and Kanying-guasi), because they manage the cattle of a large number of small livestock owners (rather than a large number of cattle of a few livestock owners). The Fulani are seen as important caretakers of the village cattle, and also better arrangements are made concerning crop compensations.

\subsection{Final Results: The Studied APDs in the ICA Model}

Concerning the enabling conditions for collective actions, resource and group characteristics are largely met, while shared norms, appropriate leadership and homogeneous identities and interests tend to lack in the studied APDs. Most necessary institutional arrangements are lacking such as locally devised rules, enforcement of those rules, sanctions, and accountable monitors. There are also no harvest restrictions, and the external environment is generally not supportive for collective action. While local authority is not undermined, supportive external sanctioning, aid and technology are lacking. Altogether, Goli has most enabling conditions, 13 out of 25, and all the others between 7 and 13 (see Table A4). As seen in Table A5, 20 out of 25 conditions can be somehow manipulated by outside interventions, however some much more directly than others. For example, determining the size of the dam upon construction is much more straightforward and direct than advising how to enforce local rules and lobbying at local governments not to undermine local authority. The results on inclusivity are summarised in Table A6. Based on the tables in the Appendix, the position of each dam with regard to successful collective action and inclusivity are shown in the ICA model below (Figure 7).

Half of the studied dams are classified as maladaptive commons because they are inclusive in the sense that different users are hardly excluded while hardly to no collective action takes place due to a lack in institutional arrangements. Two dams are classified as maladaptive clubs as these both exclude some Fulani pastoralists from using it while no collective action takes place, particularly the Takpo case because of the complete ending of any dry season farming activities due to livestock overshoots. Goli is an exceptional case, as it is both successfully managed while also highly exclusive due to the expulsion of Fulani pastoralists from the area, and is therefore classified as an adaptive club. 


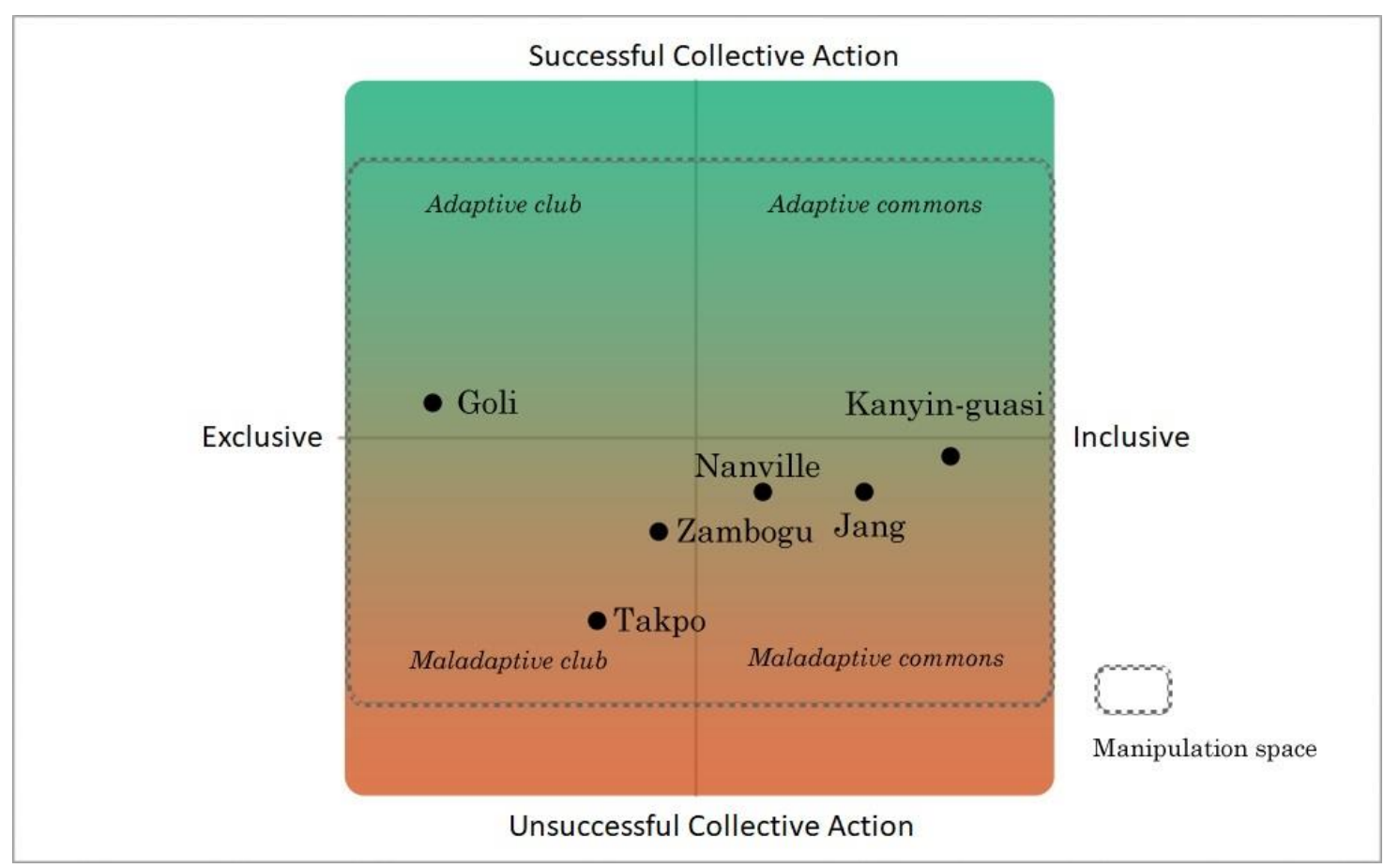

Figure 7. ICA model demonstrating the position of each studied APD and manipulation space for external interventions.

\section{Discussion}

The APDs with more successful collective action are the ones that tend to exclude certain users. In that sense, commons theorists are right for the context of this study: exclusion is indeed strongly related to-and in some cases a requirement for-collective action over a CPR system. In the studied area, exclusion takes place in two forms: One, dry season farmers are excluded due to the extensive crop damages done by increasing cattle numbers owned by local elites and Fulani pastoralists in a dam community, as happened in Takpo. From the Takpo case it is clear that the Fulani invest into 'leadership alliances' (as [34]) with the Tendamba and/or landowners, bypassing the chief if necessary as a strategy to secure their stay. Two, in another case Fulani pastoralists were not allowed to own cattle and Fulani from outside the village territory were fended off to use the dams in order to protect the dry season crops (Goli). Exposing these forms of exclusion, the ICA model reaffirmed that the empowering of communities and high self-reliance does not automatically promote sustainable management or lead to the inclusion of the most vulnerable' as pointed out by Tacconi \& Tisdell [35] and Pelling [36].

The results of this research show that widespread promotion of excludability of a resource and cultural homogeneity of users in the name of successful commons governance brings forth adaptive club types of usage. Such adaptive club communities conduct collective action themselves, but impose externalities on the region in which they are situated. In the context of Northern Ghana and possibly many other regions in West Africa, excluding cattle-owning Fulani pastoralists from using dams may lead to conflict and overuse elsewhere. Pushing for the enabling conditions for collective action may be efficient on a local scale but go at the cost of collective action in adjacent CPR systems. The results demonstrate that the enabling conditions tend to promote exclusion of diverse groups that otherwise could benefit from interventions. The promotion of power to exclude, of cultural homogeneity between commons users, and of residence near the commons-forming the core of the enabling conditions-can transform open access commons into exclusive club goods that are only used by a few. Perhaps not coincidentally, there were increases in criminal activity by Fulani pastoralists in areas where they were excluded to use the APDs (Goli). However, having fully open access APDs can also lead to conflict and overuse (Nanville and Jang). These situations are exacerbated as a blame game takes place between the 
different resource users as earlier described by Fielmua et al. [29]: while these issues occur in reality, farmers may inflate their crop damage and Fulani may inflate farmer aggression, increasing animosity between the two groups.

When diagnosing the levels of collective action by users of a CPR by only using the enabling conditions for collective action which the ICA model did-the negative external consequences of exclusion may be overlooked. The observed externalities expose an analytical weakness of the theoretical enabling conditions for collective action. Another analytical weakness of the ICA model was that all the enabling conditions have been weighed equally for the purpose of analysis. This is a strong simplification of reality, which is why the ICA model had difficulties in exposing differences in levels of collective action between APD usages that adhered a similar number of enabling conditions. Possibly, a differential weighing of the individual enabling conditions may add to a more precise diagnosis of the the APDs and other CPR systems. The study thereby reaffirmed that instead clusters of enabling conditions are needed for specific CPRs as mentioned earlier [22]. Then what clusters of enabling conditions should CBA interventions focus on in contexts where commons are aimed to be used for cultural heterogeneous, socio-economically diverse multiple user groups where, according to Bardhan \& Dayton-Johnson [12], costs of negotiation and bargaining inherent in the process of crafting commons institutions are high?

CBA interventions in northern Ghana (and other similar contexts) should focus much more on promoting local and regional institutional arrangements. Most of the dams barely met half of the enabling conditions for collective action, of which many fall under internal and external institutional arrangements. This points towards a more general problem of institutional supply concerning APDs in the studied region. While the decentralization of authority to the local level as from the 1990s in Ghana has given opportunity to APD communities to locally devise access and management rules, it has generally not led to the emergence of such rules, nor their enforcement. The studied region in Northern Ghana has demonstrated that the hardware provided by adaptation interventions-APDs-cannot be used and managed successfully in the absence of institutions that include multiple user groups. Local APD governance should include arrangements allowing Fulani pastoralists from outside to use the water while not overusing it, to oblige them or the livestock owners that contracted them to contribute to APD maintenance. Local arrangements should be complemented with advising and lobbying for regionally coherent forms of exclusion and inclusion concerning resource use by the Fulani pastoralists. The APDs should neither be open access without institutional arrangements (which is now often the case), nor should pastoralists be rigidly excluded (which is now sometimes the case), because both such scenarios lead to conflict and overuse concerning APDs within a region. CBA interventions should support local and regional arenas of discussion and deliberation where multiple stakeholders are represented on multiple scales (as proposed earlier by Ayers [37]). With contemporary CBA projects the 'software' problem of institutional supply is already supported by appointing local management committees that are supposed to monitor the resource and organize collective action. This study has demonstrated that these appointed people often do not feel this responsibility because often they have not made personal investments in the dam. For Northern Ghana, the persisting problem of institutional supply was demonstrated for the studied dams where there are 'in principle dam committees, but not in practice'. In order to become 'adaptive commons', the APDs require arrangements which incorporate contributions from both farmers and pastoralists to use and maintain a dam, maximum numbers that can use dams based on carrying capacities, and allow dam access based on water availability in other APDs in the region. If for example a dam's water levels turn very low, pastoralists could be incentivized to use dams elsewhere in the region where water may be underutilized. This study has demonstrated that regional uneven utilization of dam water is a result from a lack of coherence in Fulani inclusion. The cross-communal movement of settled Fulani in a region could be stimulated by allocating cattle-corridors to APDs. 


\section{Conclusions}

Theoretically, current commons theory that seeks to promote community empowerment in order to exclude others faces new challenges. For APDs in Northern Ghana, when empowering communities to exclude, the research has shown that it may lead to overuse and conflict in adjacent CPR systems. Either dry season farmers are excluded due to increasing cattle pressures on land surrounding APDs, or to pastoralists due to ejection of cattle-owning Fulani settlers in communities. The finding contradicts most commons theory, which suggests that excluding certain users enables successful collective action of users within a CPR system. Therefore, solely seeking to achieve the enabling conditions for collective action provides no solution on regional scales. The enabling conditions for collective action tend to overlook the regional externalities of the exclusion it promotes locally. Such exclusion is especially problematic in northern Ghana, where APD commons scattered in the landscape are available to use by mobile pastoralist groups. While providing insights on relations between collective action and inclusivity of APD systems, the proposed ICA model made this mistake by uncritically using the enabling conditions when rating success of collective action in its diagnosis of APDs. Possibly, a differential weighing of the individual enabling conditions may add to a more precise diagnosis of the quality of governance concerning CPR systems, depending on the contextual setting the CPR is situated. Further theoretical development of the enabling conditions for collective action is needed to improve current commons theory, that fits regions with culturally heterogeneous and mobile user groups of CPRs.

Practically, in northern Ghana, it is clear that CBA interventions on APDs face several challenges if more inclusive collective action is to occur by beneficiary communities in the future. Current Ghanaian adaptation discourse still sees improving water supplies through open access APDs as a magic bullet to overcome resource-related conflict and overuse. After two decades of continued establishment of open access APDs in northern Ghana, Fulani-farmer conflicts concerning land and water use continue up to today. The study has demonstrated that both rigid exclusion of certain groups on the one hand, and unbridled open access to an APD on the other hand do not lead to sustainable and inclusive APD usage. Instead, a middle ground needs to be found, where APDs are neither completely open access nor rigidly exclusive. Regionally dynamic forms of inclusion and exclusion of Fulani pastoralists are needed, based on the increasingly erratic water and pasture availabilities. These can develop if future CBA and other interventions on communal APDs complement their efforts with the development of nested local and regional institutional arrangements. In order to develop such regional arrangements, the Ghanaian government needs to change its current hostile rhetoric towards Fulani pastoralists within the discourse of its adaptation policy, into a discourse that acknowledges their important role in the usage and management of water and land CPRs throughout Ghana. When acknowledging Fulani pastoralists within the adaptation discourse, interventions need to be aware that cooperative structures between Ghanaians and settled Fulani pastoralists often involve leadership alliances to gain access to the common land and water in new territories they enter. By taking these dynamics into account, more successful and inclusive governance and use of APDs may develop, where pastoralists and farmers cooperate instead of compete. Only then, interventions can contribute to the development of adaptive commons.

Funding: This research received no external funding. The APC was funded by Utrecht University, department of Human Geography and Planning.

Acknowledgments: The research in the Upper West District of Ghana was part of a research project entitled Towards Inclusive Climate Change Interventions (TICCI), which was part of a programme called Conflict and Cooperation over the Management of Climate Change (CCMCC), funded by the Depart for International Development (DFID) of the United Kingdom, through the Netherlands Organisation for Scientific Research (NWO-WOTRO). I would like to thank Utrecht University supervisor Sebastiaan and the staff of Community Development Alliance (CDA) Ghana for all the support before, during and after the fieldwork. I would also like to express my gratitude to all the farmers and pastoralists who took the time to participate in the research.

Conflicts of Interest: The author declares no conflict of interest. 


\section{Appendix A}

Table A1. Enabling conditions for collective action and their hypothetical manipulability with external interventions ([18], based on [11]).

\begin{tabular}{|c|c|}
\hline Enabling Condition for Collective Action & $\begin{array}{l}\text { Manipulability with External } \\
\text { (Adaptation) Intervention }\end{array}$ \\
\hline \multicolumn{2}{|l|}{ 1. Resource characteristics } \\
\hline (i) Small size & No \\
\hline (ii) Well-defined boundaries & Maybe (mapping, markers) \\
\hline \multicolumn{2}{|l|}{ 2. Group characteristics } \\
\hline (i) Small size & No \\
\hline (ii) Clearly defined boundaries & No \\
\hline (iii) Shared norms & No \\
\hline (iv) Past successful experiences—social capital & $\begin{array}{l}\text { Maybe (supporting the self-organisation } \\
\text { related with other-less complex-issues) }\end{array}$ \\
\hline $\begin{array}{l}\text { (v) Appropriate leadership (young, familiar with changing external } \\
\text { environment, connected to local traditional elite) }\end{array}$ & Maybe (providing leadership training) \\
\hline (vi) Interdependence among group members & No \\
\hline (vii) Heterogeneity of endowments & No \\
\hline (viii) Homogeneity of identities and interests & Maybe (awareness raising activities) \\
\hline \multicolumn{2}{|l|}{$\begin{array}{l}\text { 3. Relationship between resource system characteristics and } \\
\text { group characteristics }\end{array}$} \\
\hline $\begin{array}{l}\text { (i) Overlap between user group residential location and } \\
\text { resource location }\end{array}$ & No \\
\hline (ii) High levels of dependence by group members on resource system & No \\
\hline (iii) Fairness in allocation of benefits from common resources & Maybe (advice) \\
\hline \multicolumn{2}{|l|}{ 4. Institutional arrangements } \\
\hline (i) Rules are simple and easy to understand & Maybe (advice) \\
\hline (ii) Locally devised access and management rules & Maybe (advice) \\
\hline (iii) Ease in enforcement of rules & Maybe (advice) \\
\hline (iv) Graduated sanctions & Maybe (advice) \\
\hline (v) Availability of low cost adjudication & Maybe (offering conflict resolution support) \\
\hline (vi) Accountability of monitors and other officials to users & Maybe (advice) \\
\hline \multicolumn{2}{|l|}{ 5. Relationship between resource system and institutional arrangements } \\
\hline (i) Match restrictions on harvests to regeneration of resources & $\begin{array}{l}\text { Yes (providing science based information on } \\
\text { regeneration patterns and the expected } \\
\text { result of restriction rules) }\end{array}$ \\
\hline \multicolumn{2}{|l|}{ 6. External environment } \\
\hline (i) Low cost exclusion technology & $\begin{array}{l}\text { Maybe (depending on the context and the } \\
\text { availability of such technology) }\end{array}$ \\
\hline (ii) Central governments should not undermine local authority & Maybe (advocacy and lobbying) \\
\hline (iii) Supportive external sanctioning institutions & $\begin{array}{l}\text { Maybe (advice on how to match local } \\
\text { sanctioning rules with existing external } \\
\text { provisions) }\end{array}$ \\
\hline $\begin{array}{l}\text { (iv) Appropriate levels of external aid to compensate local users for } \\
\text { conservation activities }\end{array}$ & $\begin{array}{l}\text { Maybe (depending on theavailable } \\
\text { resources at the disposition of the } \\
\text { external organisation) }\end{array}$ \\
\hline $\begin{array}{l}\text { (v) Nested levels of appropriation, provision, enforcement } \\
\text { and governance }\end{array}$ & Maybe \\
\hline
\end{tabular}


Table A2. Operationalisation of the enabling conditions of collective action.

\begin{tabular}{|c|c|}
\hline Enabling Condition for Collective Action & Defined and Operationalised as: \\
\hline \multicolumn{2}{|l|}{ 1. Resource characteristics } \\
\hline (i) Small size & $\begin{array}{l}\text { Dam size in which it is possible to exclude users, so that the size does } \\
\text { not hinder the possibility of monitoring users }\end{array}$ \\
\hline (ii) Well-defined boundaries & The users know what water body is part of the dam \\
\hline \multicolumn{2}{|l|}{ 2. Group characteristics } \\
\hline (i) Small size & $\begin{array}{l}\text { A group size in which communication between users is easily possible } \\
\text { through group meetings }\end{array}$ \\
\hline (ii) Clearly defined boundaries & Who is allowed to use the dam is clearly defined for all users \\
\hline (iii) Shared norms & $\begin{array}{l}\text { Presence of shared norms on how to use the resource and agreement } \\
\text { upon these by the users }\end{array}$ \\
\hline (iv) Past successful experiences—social capital & $\begin{array}{l}\text { Presence of a feeling of trust/togetherness among dam user groups, } \\
\text { and/or successful experience with communal labour concerning dam } \\
\text { construction/maintenance }\end{array}$ \\
\hline $\begin{array}{l}\text { (v) Appropriate leadership (young, familiar with } \\
\text { changing external environment, connected to } \\
\text { local traditional elite) }\end{array}$ & $\begin{array}{l}\text { Presence of a person seen by the dam users as a leader governing the } \\
\text { resource, who has connections with local landowners/chief and } \\
\text { government }\end{array}$ \\
\hline vi) Interdependence among group members & The way a user uses the dam affects the water availability for others. \\
\hline (vii) Heterogeneity of endowments & $\begin{array}{l}\text { Differences in economic assets between water users, where some can } \\
\text { make investments for maintenance which lead to differences in access to } \\
\text { the CPR }\end{array}$ \\
\hline (viii) Homogeneity of identities and interests & People share a common identity and interests in usage of the dam \\
\hline \multicolumn{2}{|c|}{ 3. Relationship between resource system characteristics and group characteristics } \\
\hline $\begin{array}{l}\text { (i) Overlap between user groups' residential } \\
\text { locations and resource locations }\end{array}$ & $\begin{array}{l}\text { User groups can reach the dam easily on foot (as many people do not } \\
\text { own vehicles) }\end{array}$ \\
\hline
\end{tabular}

\section{(ii) High levels of dependence by group members on resource system}

(iii) Fairness in allocation of benefits from common resources

4. Institutional arrangements

(i) Rules are simple and easy to understand

(ii) Locally devised access and management rules

(iii) Ease in enforcement of rules

(iv) Graduated sanctions

(v) Availability of low cost adjudication

(vi) Accountability of monitors and other officials to users

Users depend on the water to provide for their livelihood

Users consider the benefits of the dam water to be fairly allocated.

Existing rules are understood by dam users

Rules are devised by chiefs/other actors within the village and not by externals

Rules are currently enforced and there is ease in doing so.

Sanctions are enforced that become gradually more severe when a user breaks a rule concerning water use

The presence of adjudication in the region which is accessible for the users

Presence of monitors of dam and land use that are accountable to users

5. Relationship between resource system and institutional arrangements

(i) Match restrictions on harvests to regeneration of resources

Presence of restrictions on using water considering inflow rates

6. External environment

(i) Low cost exclusion technology

Technology such as fences available that helps to exclude other users.

(ii) Central governments should not undermine local authority

(iii) Supportive external sanctioning institutions

(iv) Appropriate levels of external aid to compensate local users for conservation activities

(v) Nested levels of appropriation, provision, enforcement and governance
No national or regional governments that overrule authority over dams and land by the village

Presence of police and a system of law enforcement that supports sanctioning of users

NGOs or regional government that support the users for conserving the dam

Representation of dam users (dry season farmers, pastoralists, fishers, other users) in local dam committee. Arrangements within and between villages on water use with enforcement of rules. Recognition of intraand inter-village arrangements with local government. 
Table A3. Types of inclusivity and the respective operationalised variables.

\begin{tabular}{|c|c|}
\hline Type of Inclusivity & Operationalised Variables \\
\hline $\begin{array}{l}\text { Dry season farming } \\
\text { inclusivity }\end{array}$ & $\begin{array}{l}\text { - } \quad \begin{array}{l}\text { Number of people compared to community populations using the APD } \\
\text { - }\end{array} \text { Number of farmers that sell their crops at the market } \\
\text { - } \\
\text { Number of farmer that use chemical fertilizer compared to the division of 'poor', 'middle' } \\
\text { - } \quad \text { Number of farmers that buy seeds themselves }\end{array}$ \\
\hline Fulani inclusivity & 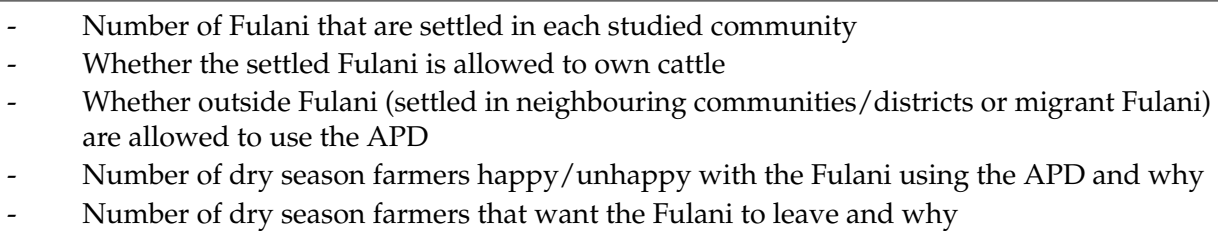 \\
\hline
\end{tabular}

Table A4. Enabling conditions for collective action met per studied dam community.

\begin{tabular}{|c|c|c|c|c|c|c|}
\hline Enabling Condition for Sustainable CPR Governance & Jang & Zam-bogo & Kanyin-guasi & Tak-po & Nan-ville & Goli \\
\hline \multicolumn{7}{|l|}{ 1. Resource characteristics } \\
\hline (i) Small size & Yes & Yes & Yes & Yes & Yes & Yes \\
\hline (ii) Well-defined boundaries & Yes & Yes & Yes & Yes & Yes & Yes \\
\hline \multicolumn{7}{|l|}{ 2. Group characteristics } \\
\hline (i) Small size & Yes & Yes & Yes & Yes & Yes & Yes \\
\hline (ii) Clearly defined boundaries & No & No & Yes & No & No & Yes \\
\hline (iii) Shared norms & Yes & No & No & No & Yes & No \\
\hline $\begin{array}{l}\text { (iv) Past successful experiences-social capital } \\
\text { (v) Appropriate leadership (young, familiar with }\end{array}$ & Yes & Yes & Yes & No & Yes & Yes \\
\hline $\begin{array}{l}\text { changing external environment, connected to local } \\
\text { traditional elite) }\end{array}$ & No & No & No & No & No & Yes \\
\hline (vi) Interdependence among group members & Yes & Yes & Yes & No & Yes & No \\
\hline (vii) Heterogeneity of endowments & Yes & Yes & Yes & Yes & Yes & Yes \\
\hline (viii) Homogeneity of identities and interests & No & No & No & No & No & No \\
\hline \multicolumn{7}{|c|}{ 3. Relationship between resource system characteristics and group characteristics } \\
\hline $\begin{array}{l}\text { (i) Overlap between user group residential location and } \\
\text { resource location }\end{array}$ & No & No & No & No & No & No \\
\hline $\begin{array}{l}\text { (ii) High levels of dependence by group members on } \\
\text { resource system }\end{array}$ & Yes & No & Yes & Yes & No & Yes \\
\hline $\begin{array}{l}\text { (iii) Fairness in allocation of benefits from common } \\
\text { resources }\end{array}$ & No & No & No & No & No & No \\
\hline \multicolumn{7}{|l|}{ 4. Institutional arrangements } \\
\hline (i) Rules are simple and easy to understand & Yes & Yes & Yes & Yes & Yes & Yes \\
\hline (ii) Locally devised access and management rules & No & No & Yes & No & No & Yes \\
\hline (iii) Ease in enforcement of rules & No & No & No & No & No & No \\
\hline (iv) Graduated sanctions & No & No & No & No & No & Yes \\
\hline (v) Availability of low cost adjudication & Yes & Yes & Yes & Yes & Yes & Yes \\
\hline (vi) Accountability of monitors and other officials to users & No & No & Yes & No & No & Yes \\
\hline \multicolumn{7}{|c|}{ 5. Relationship between resource system and institutional arrangements } \\
\hline $\begin{array}{l}\text { (i) Match restrictions on harvests to regeneration of } \\
\text { resources }\end{array}$ & No & No & No & No & No & No \\
\hline \multicolumn{7}{|l|}{ 6. External environment } \\
\hline \multirow{5}{*}{$\begin{array}{l}\text { (i) Low cost exclusion technology } \\
\text { (ii) Central governments should not undermine local } \\
\text { authority } \\
\text { (iii) Supportive external sanctioning institutions } \\
\text { (iv) Appropriate levels of external aid to compensate } \\
\text { local users for conservation activities } \\
\text { (v) Nested levels of appropriation, provision, } \\
\text { enforcement and governance }\end{array}$} & No & No & No & No & No & No \\
\hline & Yes & Yes & Yes & Yes & Yes & Yes \\
\hline & No & No & No & No & No & No \\
\hline & No & No & No & No & No & No \\
\hline & No & No & No & No & No & No \\
\hline No. of enabling conditions met & 10 & 9 & 12 & 7 & 10 & 13 \\
\hline
\end{tabular}


Table A5. Manipulability of enabling conditions for collective action for the studied APDs.

\begin{tabular}{|c|c|}
\hline Enabling Condition for Sustainable CPR Governance & Manipulatable with Dam Intervention \\
\hline \multicolumn{2}{|c|}{ 1. Resource characteristics } \\
\hline (i) Small size & Yes, construction size of dam \\
\hline (ii) Well-defined boundaries & Yes, construction of dam \\
\hline \multicolumn{2}{|c|}{ 2. Group characteristics } \\
\hline (i) Small size & Yes, size of dam and allocation to beneficiaries \\
\hline (ii) Clearly defined boundaries & Yes, informing who can use it, open access or not \\
\hline (iii) Shared norms & No \\
\hline (iv) Past successful experiences—social capital & No \\
\hline $\begin{array}{l}\text { (v) Appropriate leadership (young, familiar with changing } \\
\text { external environment, connected to local traditional elite) }\end{array}$ & Yes, organize leadership appointment \\
\hline (vi) Interdependence among group members & No \\
\hline (vii) Heterogeneity of endowments & No \\
\hline (viii) Homogeneity of identities and interests & No \\
\hline \multicolumn{2}{|c|}{ 3. Relationship between resource system characteristics and group characteristics } \\
\hline $\begin{array}{l}\text { (i) Overlap between user group residential location and } \\
\text { resource location }\end{array}$ & Yes, aim to build dams near farmer's residential location \\
\hline $\begin{array}{l}\text { (ii) High levels of dependence by group members on } \\
\text { resource system }\end{array}$ & $\begin{array}{c}\text { No, but only build dams if needed to maintain livelihoods and } \\
\text { not just as side-activity }\end{array}$ \\
\hline $\begin{array}{l}\text { (iii) Fairness in allocation of benefits from } \\
\text { common resources }\end{array}$ & Yes, again focus on that both rich and poor can use the dam \\
\hline \multicolumn{2}{|c|}{ 4. Institutional arrangements } \\
\hline (i) Rules are simple and easy to understand & Yes, advice on rules to use \\
\hline (ii) Locally devised access and management rules & Yes, advice on rules to use \\
\hline (iii) Ease in enforcement of rules & Yes, advice on how to enforce rules \\
\hline (iv) Graduated sanctions & Yes, advice on possible sanctions \\
\hline (v) Availability of low cost adjudication & Yes, offer conflict resolution support \\
\hline (vi) Accountability of monitors and other officials to users & Yes, advice on who monitors (preferably users themselves) \\
\hline \multicolumn{2}{|c|}{ 5. Relationship between resource system and institutional arrangements } \\
\hline $\begin{array}{l}\text { (i) Match restrictions on harvests to regeneration of } \\
\text { resources }\end{array}$ & $\begin{array}{l}\text { Yes (providing science based information on regeneration } \\
\text { patterns and the expected result of restriction rules) }\end{array}$ \\
\hline \multicolumn{2}{|c|}{ 6. External environment } \\
\hline (i) Low cost exclusion technology & $\begin{array}{l}\text { Yes (indirectly), provide loans for fences or fences directly } \\
\text { (depending to what extent pastoralists are aimed to be excluded) }\end{array}$ \\
\hline $\begin{array}{l}\text { (ii) Central governments should not undermine local } \\
\text { authority }\end{array}$ & $\begin{array}{c}\text { Yes (indirectly), advocacy and lobbying as part of } \\
\text { interventions [18] }\end{array}$ \\
\hline (iii) Supportive external sanctioning institutions & $\begin{array}{l}\text { Yes (indirectly) advice on how to match local sanctioning rules } \\
\text { with existing external provisions [18] }\end{array}$ \\
\hline $\begin{array}{l}\text { (iv) Appropriate levels of external aid to compensate local } \\
\text { users for conservation activities }\end{array}$ & $\begin{array}{l}\text { Yes, but for dams only relevant for preservation of } \\
\text { fish/crocodile species }\end{array}$ \\
\hline $\begin{array}{l}\text { (v) Nested levels of appropriation, provision, enforcement } \\
\text { and governance }\end{array}$ & $\begin{array}{l}\text { Yes (indirectly), inform on representation of irrigation sections } \\
\text { and pastoralists from different areas into local and regional } \\
\text { governance bodies }\end{array}$ \\
\hline
\end{tabular}


Table A6. Summary of results on inclusivity.

\begin{tabular}{|c|c|c|c|c|c|}
\hline \multirow[b]{2}{*}{ Village } & \multirow{2}{*}{$\begin{array}{c}\begin{array}{c}\text { Inclusivity of Dry } \\
\text { Season Farmers }\end{array} \\
\begin{array}{c}\text { Socio-Economic } \\
\text { Diversity of Farmers }\end{array}\end{array}$} & \multicolumn{3}{|c|}{ Inclusivity of Fulani Pastoralists } & \multirow{2}{*}{$\begin{array}{c}\text { Overall } \\
\text { Inclusivity }\end{array}$} \\
\hline & & $\begin{array}{c}\text { Host Cattle- } \\
\text { Owning Fulani }\end{array}$ & $\begin{array}{l}\text { No. of Farmers } \\
\text { that Want the } \\
\text { Fulani to Leave }\end{array}$ & $\begin{array}{l}\text { Stance towards } \\
\text { Fulani from Outside } \\
\text { Community }\end{array}$ & \\
\hline Zambogo & High & No & - & Very negative & Low \\
\hline Takpo & Low (mainly rich) & Yes & High & Negative & Low \\
\hline Kanyin-guasi & High & Yes & Low & Negative & High \\
\hline Nanville & Moderate (mainly poor) & Yes & High & Negative & Moderate \\
\hline Jang & Moderate (mainly rich) & Yes & Low & Negative & High \\
\hline Goli & High & No & Moderate & Very negative & Very low \\
\hline
\end{tabular}

\section{References}

1. Kpéra, G.N.; Aarts, N.; Saïdou, A.; Tossou, R.C.; Eilers, C.H.A.M.; Mensah, G.A.; Sinsin, B.A.; Kossou, D.K.; Van der Zijpp, A.J. Management of agro-pastoral dams in Benin: Stakeholders, institutions and rehabilitation research. NJAS-Wagen. J. Life Sci. 2012, 60, 79-90.

2. Dodman, D.; Mitlin, D. Challenges for community-based adaptation: Discovering the potential for transformation. J. Int. Dev. 2013, 25, 640-659. [CrossRef]

3. Ostrom, E. Governing the Commons: The Evolution of Institutions for Collective Action; Cambridge University Press: Cambridge, UK, 1990.

4. Williams, T.O. Multiple uses of common pool resources in semi-arid West Africa: A survey of existing practices and options for sustainable resource management. Nat. Resour. Perspect. 1998, 38, 1-8.

5. Moritz, M. Changing contexts and dynamics of farmer-herder conflicts across West Africa. Can. J. Afr. Stud. 2006, 40, 1-40. [CrossRef]

6. Moritz, M. Understanding herder-farmer conflicts in West Africa: Outline of a processual approach. Hum. Organ. 2010, 69, 138-148. [CrossRef]

7. Tonah, S. State policies, local prejudices and cattle rustling along the Ghana-Burkina Faso border. Africa 2000, 70, 551-567. [CrossRef]

8. Tonah, S. Fulani pastoralists, indigenous farmers and the contest for land in Northern Ghana. Afr. Spectrum 2002, 37, 43-59.

9. Turner, M.D.; McPeak, J.G.; Ayantunde, A. The role of livestock mobility in the livelihood strategies of rural peoples in semi-arid West Africa. Hum. Ecol. 2014, 42, 231-247. [CrossRef]

10. Ostrom, E. Constituting Social Capital and Collective Action. J. Theor. Polit. 1994, 6, 527-562. [CrossRef]

11. Agrawal, A. Common property institutions and sustainable governance of resources. World Dev. 2001, 29, 1649-1672. [CrossRef]

12. Bardhan, P.; Dayton-Johnson, J. Unequal irrigators: Heterogeneity and commons management in large-scale multivariate research. In The Drama of the Commons; The National Academies Press: Washington, DC, USA, 2002; pp. 87-112.

13. Hardin, G. The Tragedy of the Commons. Science 1968, 162, 1243-1248. [PubMed]

14. Twyman, C.; Long, A.; Vaughan, C. Community-based institutions and water resource management in drylands. In Zayed Conference: Water Resources and Integrated Management in the Third Millennium; Zayed International Price for the Environment: Dubai, UAE, 2002; pp. 2-6.

15. Beyene, F.; Korf, B. 10 Unmaking the Commons: Collective Action, Property Rights, and Resource Appropriation among (Agro-) Pastoralists in Eastern Ethiopia. In Collective Action and Property Rights for Poverty Reduction: Insights from Africa and Asia; IFPRI: Washington, DC, USA, 2012; p. 304.

16. Pretty, J. Social capital and the collective management of resources. Science 2003, 302, 1912-1914. [CrossRef] [PubMed]

17. Adger, W.N. Social capital, collective action, and adaptation to climate change. In Der klimawandel; VS Verlag für Sozialwissenschaften: Wiesbaden, Germany, 2010; pp. 327-345.

18. Van Laerhoven, F.; Barnes, C. Communities and commons: The role of community development support in sustaining the commons. Community Dev. J. 2014, 49 (Suppl. 1), i118-i132. [CrossRef] 
19. Barnes, C.; Laerhoven, F.V. Helping to Self-Help? External Interventions to Stimulate Local Collective Action in Joint Forest Management, Maharashtra, India. Int. For. Rev. 2013, 15, 1-17. [CrossRef]

20. Barnes, C.; van Laerhoven, F. Making it last? Analysing the role of NGO interventions in the development of institutions for durable collective action in Indian community forestry. Environ. Sci. Pol. 2015, 53, 192-205. [CrossRef]

21. Cox, M.; Arnold, G.; Tomás, S.V. A review of design principles for community-based natural resource management. Ecol. Soc. 2010, 15, 38. [CrossRef]

22. Baggio, J.; Barnett, A.; Perez-Ibarra, I.; Brady, U.; Ratajczyk, E.; Rollins, N.; Rubiños, C.; Shin, H.; Yu, D.; Aggarwal, R.; Anderies, J. Explaining success and failure in the commons: the configural nature of Ostrom's institutional design principles. IJC 2016, 10, 417-439. [CrossRef]

23. Thomas, D.S.; Twyman, C. Equity and justice in climate change adaptation amongst natural-resource dependent societies. Glob. Environ. Chang. 2005, 15, 115-124. [CrossRef]

24. Agrawal, A.; Gibson, C.C. Enchantment and disenchantment: The role of community in natural resource conservation. World Dev. 1999, 27, 629-649. [CrossRef]

25. Leach, M.; Mearns, R.; Scoones, I. Environmental entitlements: Dynamics and institutions in communitybased natural resource management. World Dev. 1999, 27, 225-247. [CrossRef]

26. Ribot, J.C.; Peluso, N.L. A theory of access. Rural Sociol. 2003, 68, 153-181. [CrossRef]

27. Adger, W.N.; Huq, S.; Brown, K.; Conway, D.; Hulme, M. Adaptation to climate change in the developing world. Prog. Dev. Stud. 2003, 3, 179-195. [CrossRef]

28. Few, R.; Brown, K.; Tompkins, E.L. Public participation and climate change adaptation: Avoiding the illusion of inclusion. Clim. Policy 2007, 7, 46-59. [CrossRef]

29. Fielmua, N.; Bandie, R.D.B.; Ziemah, M.K. Managing Pastoralism and Water Rights in the Upper West Region of Ghana: A Blame Game among Actors. J. Sustain. Dev. 2014, 7. [CrossRef]

30. Namara, R.E.; Horowitz, L.; Nyamadi, B.; Barry, B. Irrigation Development in Ghana: Past Experiences, Emerging Opportunities, and Future Directions; Ghana Strategy Support Program (GSSP) Working Paper; Ghana Strategy Support Program (GSSP): Accra, Ghana, 2011.

31. Tonah, S. Integration or exclusion of Fulbe pastoralists in West Africa: A comparative analysis of interethnic relations, state and local policies in Ghana and Côte d'Ivoire. J. Mod. Afr. Stud. 2003, 4, 91-114. [CrossRef]

32. Breusers, M.; Nederlof, S.; Van Rheenen, T. Conflict or symbiosis? Disentangling farmer-herdsman relations: The Mossi and Fulbe of the Central Plateau, Burkina Faso. J. Mod. Afr. Stud. 1998, 36, 357-380. [CrossRef]

33. CARE Ghana. Wealth Ranking Scales for ALP Sites Communities; CARE Ghana: Tamale, Ghana, 2015.

34. Yembilah, R.; Grant, M. The political ecology of territoriality: Territorialities in farmer-herder relationships in Northern Ghana. GeoJournal 2014, 79, 385-400. [CrossRef]

35. Tacconi, L.; Tisdell, C. Rural development projects in LDCs: Appraisal, participation and sustainability. Public Admin. Dev. 1992, 12, 267-278. [CrossRef]

36. Pelling, M. The Vulnerability of Cities: Natural Disasters and Social Resilience; Earthscan: London, UK, 2003.

37. Ayers, J. Understanding the Adaptation Paradox: Can Global Climate Change Adaptation Policy Be Locally Inclusive? Ph.D. Thesis, The London School of Economics and Political Science, London, UK, 2010.

(C) 2019 by the author. Licensee MDPI, Basel, Switzerland. This article is an open access article distributed under the terms and conditions of the Creative Commons Attribution (CC BY) license (http://creativecommons.org/licenses/by/4.0/). 